\title{
MIGRACIJE I PRAVO NA RAD U EUROPSKOJ UNIJI
}

Doc. dr. sc. Ivana Vukorepa*

UDK: 331.5:314.7(4)EU

339.923:061.1>(4)EU

342.734(4)EU

Izvorni znanstveni rad

Primljeno: veljača 2018.

Svrha ovog rada jest analizirati i prikazati pravno uređenje prava na rad $u$ EU-u u kontekstu problematike migracija. S obzirom na to da migracije općenito, a posebno radne migracije imaju svoje raznovrsne uzroke, te važne gospodarske, društvene i demografske posljedice, u radu se prvo daje prikaz temeljnih pojmova, povijesnog razvoja i značajki u vezi s migracijama. Naznačuju se njezini najvažniji društveno-ekonomski i pravni aspekti te elementi tržišta rada koji su relevantni za migracije. $U$ drugom dijelu rada detaljno se razrađuje normativno uređenje radnih migracija u EU-u. Pravi se jasna razlika između prava na rad državljana država članica EU-a i državljana trećih zemalja. Naglasak je stavljen na slobodu kretanja radnika, upućene radnike i prijelazni režim za državljane iz novih država članica.

Ključne riječi: migracije, sloboda kretanja radnika, EU, upućeni radnici

\section{UVOD}

Migracije možemo razlikovati s obzirom na razloge odnosno svrhu migriranja. Tako npr. postoje radne (ekonomske), obiteljske, obrazovne te političke i ratne migracije (što uključuje izbjeglice i tražitelje azila). S obzirom na trajanje raspoznajemo trajne, privremene i sezonske migrante (to posebice kod radnih migracija). Razlikujemo zemlje emigracije, iz kojih migranti odlaze, i zemlje

* Dr. sc. Ivana Vukorepa, docentica Pravnog fakulteta Sveučilišta u Zagrebu, Trg Republike Hrvatske 14, Zagreb, ivana.vukorepa@pravo.hr;

ORCID ID: orcid.org/0000-0001-6759-9992.

1 Dio ovog rada je rezultat istraživanja provedenog u okviru znanstveno istraživačkog projekta "Novi hrvatski pravni sustav" na Pravnom fakultetu Sveučilišta u Zagrebu. 
imigracije, u koje migranti dolaze sa željom da se tamo privremeno ili trajnije nastane. $^{2}$

Važan čimbenik uspješne integracije stranaca u društvo je i njihova mogućnost zaposlenja. Premda kroz povijest nalazimo primjere zemalja koje su priznavale strancima pravo na nastanjenje i rad bez ograničenja ${ }^{3}$, danas takav slobodan režim postoji samo među povezanim država, kao što su npr. zemlje članice EU-a. S obzirom na to da je RH članica EU-a od 1. srpnja 2013., glavni predmet interesa u ovom radu je pravo na rad u EU-u. Međutim, radi cjelovitosti uvida u materiju, u prvom dijelu rada smatramo potrebnim prikazati važnija povijesna obilježja i teorijska razmatranja u vezi s društvenim, ekonomskim i pravnim aspektima migracija. Drugi dio rada posvećen je uređenju materije radnih migracija u okviru prava EU-a. Objašnjena je razlika između prava na rad državljana država članica EU-a i državljana trećih zemalja. U radu je stavljeno težište na slobodu kretanja radnika, upućene radnike i prijelazni režim za državljane iz novih država članica. Daje se kritički pregled uvjeta pod kojima državljani država članica EU-a i povezanih država smiju raditi te se skreće pažnja na brojne iznimke. Rad je napisan na temelju analize primarnih i sekundarnih izvora prava EU-a, sudske prakse Suda EU-a te istraživanja odgovarajuće stručne i znanstvene literature. ${ }^{4}$

\section{POVIJESNA I TEORIJSKA RAZMATRANJA O MIGRACIJAMA}

\subsection{Povijesna obilježja}

Raznoliki su povijesni razlozi i obilježja migracija, a uvjetovane su ratnim osvajanjima i vojnim interesima, političkim i gospodarskim savezima, prirodnim katastrofama, tehnološkim razvojem, javnim politikama i nestabilnostima na tržištu rada. Migracije su u svijetu krajem 19. i početkom 20. st. obilježili nekvalificirani radnici. Najčešće destinacije Europljana (posebice državljana Irske, UK-a, skandinavskih zemalja, Njemačke, a poslije i južnoeuropskih i istočnih

2 Zemlje emigracije nazivaju se još i države podrijetla ili države slanja (engl. emigration state, home state, sending country; njem. Herkunftsstaat; fr. pays d'emigration; l'état d'origine), dok se zemlje imigracije nazivaju još i države primateljice ili države odredišta, destinacije ili prijma (engl. immigration state, host state, receiving country; njem. Aufnahmestaat; fr. pays d'immigration, l'état d'accueil).

3 Tintić, N., Radno i socijalno pravo, Knjiga prva: Radni odnosi (II), Narodne novine, Zagreb, 1972., str. 42.

4 Pri pisanju autorica se koristi i nekim svojim starijim radovima objavljenim iz ovog područja koji će biti navedeni na odgovarajućim mjestima. 
država) u počecima su bile prekomorske zemlje. Do Prvog svjetskog rata to je ponajprije bio SAD, čije je tržište zbog druge industrijske revolucije potraživalo radnu snagu. Poslije, uslijed restriktivnije imigracijske politike, sreća se tražila u Australiji, Kanadi i Novom Zelandu. ${ }^{5}$ Tijekom 50-ih i 60-ih godina 20. st. zbog gospodarske obnove i industrijskog razvoja kapitalističkih država Europe, zemlje poput Njemačke, Belgije, Nizozemske i Francuske postaju sve privlačnije imigrantima. ${ }^{6}$ Zbog kolonijalnih veza ekonomske i kulturne međuovisnosti bivše kolonijalističke sile bilježe veći priljev migranata iz zemalja tzv. Trećeg svijeta. ${ }^{7}$ Naftna kriza 70-ih godina donosi preokret te imigrantske države počinju poticati povratak imigranata $u$ zemlje podrijetla. ${ }^{8}$ Ponovni gospodarski povoljni uvjeti s kraja 20. st. sve do financijske krize 2009. godine privlače imigrante. Tako i neke tradicionalno emigrantske zemlje postaju privlačne za migrante (npr. Italija, Irska, Španjolska). ${ }^{9}$ U pogledu poslova koje migranti obavljaju primjetan je selektivan probir migranata uslijed sve veće segmentiranosti tržišta rada. U drugoj polovici 20. st., a posebice u 21. st., uz i nadalje prisutnu potrebu za niže kvalificiranim radnicima u građevinarstvu, poljoprivredi i uslužnim sektorima, dolazi do sve veće potražnje za visoko kvalificiranim imigrantima u gospodarski i tehnološki naprednim državama. ${ }^{10}$

5 Prema: Župarić-Iljić, D.; Bara, M., Unutrašnje i vanjske migracije u Hrvatskoj: povijesni i suvremeni kontekst, u: Puljiz, V. et al. (ur.), Migracije i razvoj Hrvatske: podloga za hrvatsku migracijsku strategiju, Hrvatska gospodarska komora, Zagreb, 2014., str. 197 - 200; Puljiz, V.; Migracije i imigracijske politike u Europi, u: Puljiz, V. et al. (ur.), Migracije i razvoj Hrvatske: podloga za hrvatsku migracijsku strategiju, Hrvatska gospodarska komora, Zagreb, 2014., str. $252-254$.

6 Ibid.

7 Mesić objašnjava uzroke migracija u kolonijalnoj ekspanziji, industrijalizaciji i globalizaciji. Ukidanje prepreka slobodnom protoku roba i kapitala u zaostala gospodarstva rezultira stvaranjem golemog viška radne snage i emigracijskog potencijala u tim zemljama. (Mesić, M., Međunarodne migracije, u: Puljiz, V. et al. (ur.), Migracije i razvoj Hrvatske: podloga za hrvatsku migracijsku strategiju, Hrvatska gospodarska komora, Zagreb, 2014., str. 157, 168, 172).

8 Puljiz, op. cit. u bilj. 5, str. 253.

9 O promjenjivosti migracijskih trendova u EU-u vidi npr.: 1) O'Leary, S., The Free Movement of Persons and Services, u: Craig, P., de Búrca, G. (ur.), The Evolution of EU Law, Oxford University Press, New York, 1999., str. 386 - 392; 2) Urso, G.; Schuster A., Migration, Employment and Labour Market Integration Policies in the EU (2011), International Organisation for Migration, Brussels, 2013.; 3) Canetta, E.; Fries-Tersch, E.; Mabilia, V., 2014 Annual report on statistics on intra-EU movers, European Commission, September 2014.

10 Vidi npr.: O’Leary, op. cit. u bilj. 9, str. 390. Arslan, C.; Dumont, J.; Kone, Z.; Moullan, Y.; Ozden, C.; Parsons, C.; Xenogiani; T., A New Profile of Migrants in the 
Danas više od 250 milijuna ljudi živi izvan svoje zemlje rođenja. Iako je broj međunarodnih migranata povećan sa 175 milijuna u 2000. godini na više od 251 milijuna u 2015. godini, udio migranata u svjetskoj populaciji u posljednjih se petnaest godina kreće oko tri posto (u 2015. cca 3,4\% svjetske populacije). ${ }^{11}$ Sličan omjer primjetan je i u EU-u. Udio državljana EU-a koji prebivaju u drugoj državi članici kreće se između dva i tri posto stanovništva EU-a (npr. 2,4 \% u 2008., 2,8 \% u 2012., $3.1 \%$ u 2013.), dok je udio državljana trećih država u EU-u veći (cca. 4 \%). ${ }^{12}$ U svijetu su najatraktivnije zemlje odredišta SAD, Saudijska Arabija, Njemačka, Rusija, Ujedinjeni Arapski Emirati, UK, Francuska, Kanada, Španjolska i Australija, dok su zemlje najbrojnije emigracije Indija, Meksiko, Rusija, Kina i Bangladeš. ${ }^{13}$ Europa je atraktivna imigrantima sa Bliskog istoka i iz afričkih zemalja koji uslijed nestabilnosti i ratnih sukoba traže zaklon i bolji život.

U okviru EU-a radne migracije zauzimaju najznatniji dio. U 2015. godini u drugoj državi članici EU-28 živjelo je 11,3 milijuna radno sposobnih osoba u dobi između 20 i 64 godine života. Od tog broja njih je oko 8,5 milijuna bilo zaposleno ili tražilo posao. Nadalje, 1,3 milijuna građana EU-a prebivalo je u jednoj državi članici tijekom rada u drugoj državi članici. Osim toga, u 2015. godini bilo je 1,4 milijuna umirovljenih državljana EU-28 koji su živjeli u državi članici različitoj od zemlje državljanstva. ${ }^{14}$ Njemačka je već dugi niz godina glavna imigracijska destinacija, a slijede je UK, Španjolska, Francuska i Italija, te Švicarska kada se uzmu u obzir i podaci za cijeli Europski gospodarski prostor (EGP). Najveći broj emigranata u EU-u dolazi iz Rumunjske, Poljske, Njemačke, Italije i Francuske. ${ }^{15}$ Ipak treba primijetiti da unutar EU-a postoji i tendencija vraćanja u državu podrijetla (engl. return mobility). ${ }^{16}$

Aftermath of the Recent Economic Crisis, OECD Social, Employment and Migration Working Papers, br. 160, 2014., OECD Publishing, http://dx.doi.org/10.1787/5jxt2t3nnjr5-en, str. $11-12$.

11 World Bank, Migration and Remittances Factbook, 3. izdanje, The World Bank, Washington, 2016., str. v.

12 European Commission, COM (2013) 837 final, od 25. studenoga 2013., str. 3. Canetta et al., op. cit. u bilj. 9, str. 1.

13 World Bank, op. cit. u bilj. 11, str. v.

14 Fries-Tersch, E.; Tugran, T.; Bradley, H., 2016 Annual Report on intra- EU Labour Mobility, European Commission, 2. izdanje, svibanj 2017., str. 21 - 22.

15 Ibid. Također vidi Canetta et al., op. cit., u bilj. 9, str., str. 6, 8-9, 17, 19.

16 Više vidi u: Fries-Tersch et al., op. cit. u bilj. 14, str. 12 - 13, 33, 81 - 115. 
Hrvatska, nažalost primarno zemlja emigracije $\mathrm{e}^{17}$, pamti i razdoblja imigracije. U doba kada je bila dijelom Habsburške Monarhije, većinu su useljenika u Hrvatsku činili imigranti iz drugih dijelove Monarhije. Nakon toga, dok je Hrvatska bila u sastavu bivše Jugoslavije, dominiraju ekonomske i obrazovne migracije iz ostalih republika te država europskog jugoistoka. ${ }^{18}$ Povijesne veze te prostorna blizina obilježavaju i današnju imigrantsku sliku Hrvatske. Od ukupnog broja stranih državljana na stalnom i privremenom boravku u RH (na kraju 2015. ukupno 26.639 osoba iz oko 120 zemalja, u koji broj ne ulaze njihovi članovi obitelji) njih su 51,04 \% državljani iz zemalja Europskog gospodarskog prostora, a 48,96 \% državljani trećih država. Najveći broj stranaca podrijetlom je iz Bosne i Hercegovine (25,09 \%), Slovenije (11,99 \%), Njemačke (11,32 \%), Italije (6,3 \%) i Austrije (3,1 \%). ${ }^{19}$ Povećan broj migranata iz Njemačke, Italije i Austrije čine pretežito korporativni migranti, koji su zaduženi za provođenje stranih investicija te upravljanje i kontrolu stranim kompanijama u Hrvatskoj.

Emigracija iz Hrvatske od 19. st. nadalje bila je ponajprije motivirana nepovoljnim gospodarskim prilikama i političkim neprilikama. Na emigraciju su znatno utjecale deagrarizacija, regionalne različitosti te izostanak prostorne komponente razvoja i usmjeravanja investicija, pa su osobe koje nisu mogle naći zaposlenje u nekoliko većih gradova (primarno Zagreb, Split i Rijeka), potražile utočište $u$ inozemstvu. ${ }^{20}$ Hrvatska je nažalost i danas ponovno suočena s odljevom svojeg stanovništva, najčešće mladih i školovanih. U 2013. godini 10 \% našeg radno sposobnog stanovništva prebivalo je u nekoj drugoj državi članici EU-a, a čak je 62 \% naših emigranata u dobi između 15 i 34 godine života (udio u EU-27 jest 37 \%). ${ }^{21}$ Prije pristupanja EU-u najveći broj emigranata odlazio je u Njemačku, Austriju, Italiju, UK i Sloveniju. I nakon 2013. to ostaju

17 Demografski izračuni upućuju na činjenicu da je iseljavanje iz Hrvatske gotovo uvijek dominiralo nad useljavanjem, pa je prema nekim proračunima Hrvatsku tijekom 20. st. napustilo 1,2 milijuna stanovnika više nego što se u nju uselilo. Vidi Gelo, J.; Akrap, A.; Čipin, I., Temeljne značajke demografskog razvoja Hrvatske - Bilanca 20. stoljeća, Zagreb, Ministarstvo obitelji, branitelja i međugeneracijske solidarnosti, 2005., a navodi se prema: Župarić-Iljić, D.; Bara, M., op. cit. u bilj. 5, str. 200.

18 Ibid., str. 197, 200. Vidi također Ravnić, A.; Potočnjak, Ž., Pravni aspekti odlaska stručnjaka u inozemstvo, Institut za društvena istraživanja Sveučilišta u Zagrebu, Zagreb, 1986., str. 12 - 119.

19 Autorica izračunala na temelju statističkih podataka MUP-a (podaci na dan 31. prosinca 2015.), http://www.mup.hr/main.aspx?id=172024 (8. ožujka 2016.).

20 Akrap, A., Promjene broja i prostornog razmještaja stanovništva Hrvatske $i$ županija, u: Puljiz, V. et al. (ur.), Migracije i razvoj Hrvatske: podloga za hrvatsku migracijsku strategiju, Hrvatska gospodarska komora, Zagreb, 2014., str. 26, 67 - 69.

21 European Commission, COM (2015) 233 final, 29. svibnja 2015., str. 4, 6, 8 - 9. 
najprivlačnije destinacije, uz primjetan porast broja osoba koje odlaze u Irsku i Švedsku. ${ }^{22}$ Takav znatan "odljev mozgova" (engl. brain drain) i "odljev mladih" (engl. youth drain) ozbiljna je prijetnja demografskoj održivosti i gospodarskom razvoju Hrvatske. Dodatan je problem gubitak radne snage u pojedinim sektorima, kao npr. kod nas u zdravstvu. ${ }^{23}$

\subsection{Društveni i ekonomski aspekti migracija}

Razlozi zbog kojih ljudi migriraju mnogobrojni su, premda se u svojoj biti uvijek svode na potragu za boljom kvalitetom života i većom zaradom. Često ih se svrstava u tzv. čimbenike poticanja na odlazak iz države (engl. push factors) i čimbenike privlačenja u drugu državu ili povratka u državu podrijetla (engl. pull factors). Ti su čimbenici raznovrsni te ih prema navodima u dostupnoj literaturi ${ }^{24}$ odlučujemo grupirati na sljedeći način: 1) ekonomski razlozi kao što su siromaštvo, nezaposlenost ili nepovoljna poduzetnička i ulagačka klima, koji djeluju kao čimbenici poticanja na odlazak, te nasuprot tome mogućnost ostvarivanja veće zarade, boljih životnih i radnih uvjeta u drugim državama, koji djeluju kao čimbenici privlačenja ${ }^{25}$; 2) politički razlozi kao što su ratovi, građanski sukobi, nesigurnost zbog političkih sklonosti i vjerskog opredjeljenja te nepoštovanje ljudskih prava nasuprot zemljama u kojima je zajamčena osobna i pravna sigurnost te političke slobode; 3) prirodni (klimatski) razlozi kao što su kišna, poplavna i sušna područja naspram klimatski ugodnijih podneblja, 4) socijalni i kulturološki razlozi poput nepoštovanja građanskih prava, raslojenosti

22 Više vidi u: European Commission, COM (2015) 233 final, 29. svibnja 2015., str. 4; European Commission, SWD (2015) 107 final, 29. svibnja 2015., str. 5 - 6; Fries-Tersch et al., op. cit. u bilj. 14.

23 Premda se o tom problemu govori u Hrvatskoj tek od pristupanja Hrvatske EU-u, on postoji od prije. Prema podacima OECD-a u 2010./2011. broj hrvatskih liječnika koji su radili u nekoj od država OECD-a iznosio je 836, a broj medicinskih sestara 3.589 (OECD, International Migration Outlook 2015, OECD Publishing, Pariz, http:// dx.doi.org/10.1787/migr_outlook-2015-en, str. 178.

24 Vidi npr. Bejaković, P. Obrazovanje, Tržište rada i mobilnost radne snage u Hrvatskojstanje i problemi, u: Puljiz, V. et al. (ur.), Migracije i razvoj Hrvatske: podloga za hrvatsku migracijsku strategiju, Hrvatska gospodarska komora, Zagreb, 2014., str. 104.; Obadić, A., Posljedice ekonomske krize na tržište rada i mobilnost radne snage u EU i RH, u: Puljiz, V. et al. (ur.), Migracije i razvoj Hrvatske: podloga za hrvatsku migracijsku strategiju, Hrvatska gospodarska komora, Zagreb, 2014., str. 150; Mesić, op. cit. u bilj. 7, str. 161.

25 Međutim, i tu treba uzeti u obzir i druge odrednice kvalitete života u zemlji podrijetla u odnosu na željenu destinaciju, s obzirom na to da i ostali troškovi mogu znatno smanjiti zaradu (npr. troškovi stanovanja, zdravstvenih usluga, prijevoza itd.). 
društva na temelju etničke, rasne, spolne ili vjerske pripadnosti, te nedostatak obrazovnih usluga nasuprot čimbeniku privlačenja poput spajanja obitelji, prijateljskih veza, migrantskih društvenih mreža te povoljne imigracijske politike i povijesnih povezanosti.

Rast međunarodnih migracija kao dijela globalnog procesa objašnjava se nekim od sljedećih uzroka: 1) nejednaka razvijenost država slanja i primitaka, 2) rastuća povezanost svih razvijenih gospodarstava i 3) promjene na tržištu rada. ${ }^{26}$

Migracije mogu imati i pozitivne i negativne posljedice i na državu primateljicu i na državu podrijetla. Među pozitivnim učincima najčešće se spominje popunjavanje sezonskih poslova i deficitarnih zanimanja, povećanje fiskalnih prihoda (posebno u obliku uplate poreza radnih imigranata) ${ }^{27}$ te priljev mlađe populacije, što pomaže demografskoj obnovi ostarjelih društava. Za države podrijetla obično se ističe pozitivan učinak na smanjenje nezaposlenosti. Nadalje, u slučajevima povratka u domovinu (kod tzv. cirkularnih migracija), postoje i tzv. pozitivni povratni učinci u obliku npr. novčanih doznaka članovima obitelji ili ušteđevine, povratka nakon stjecanja novih znanja i vještina, mogućnost stvaranja poslovnih i trgovačkih mreža. ${ }^{28} \mathrm{U}$ slučaju migracija iz kapitalom bogatih zemalja u siromašnije (u obliku investicija i pokretanja poslovanja) dolazi do migriranja tzv. ključnog osoblja, transfera znanja i tehnologija, stvaranja novih mreža suradnje te poticanja razvoja gospodarstva.

Među negativnim posljedicama u državama odredišta najčešće se spominje problem povećanja rashoda u sustavima socijalne sigurnosti (posebice socijalne pomoći) te nepovoljan utjecaj na kulturni identitet. ${ }^{29}$ Poseban problem može biti nezaposlenost mladih imigranata (npr. na području OECD-a među migrantima iz Afrike doseže čak $37 \%$ ). ${ }^{30}$ Najproblematičnije posljedice u državama emigracije (podrijetla) zasigurno su povezane s odljevom osoba u fertilnoj dobi

26 O teorijskim objašnjenjima za migracije vidi: Mesić, op. cit. u bilj. 7, str. $161-172$.

O fiskalnim učincima imigranata vidi: OECD, International Migration Outlook 2013, OECD Publishing, Pariz, str. 125 - 189.

28 Tako npr. Čavrak, V., Utjecaj migracija visokoobrazovanih stručnjaka na razvoj Hrvatske, u: Puljiz, V. et al. (ur.), Migracije i razvoj Hrvatske: podloga za hrvatsku migracijsku strategiju, Hrvatska gospodarska komora, Zagreb, 2014., str. 121; Skupnjak Kapić, S., Migracije radne snage - globalni i europski trendovi s osvrtom na Hrvatsku, u: Puljiz, V. et al. (ur.), Migracije i razvoj Hrvatske: podloga za hrvatsku migracijsku strategiju, Hrvatska gospodarska komora, Zagreb, 2014., str. 232.

29 Vonk, G.; van Walsum, S., Towards a new approach to social protection for formally excluded migrants, u: Vonk, G. (ur.), Cross Border Welfare State: Immigration, Social Security and Integration, Intersentia, Cambridge, 2012., str. 3 - 4.

$30 \quad$ Arslan et al., op. cit. u bilj. 10, str. 33. 
i visokoobrazovanih (tzv. odljev mozgova i mladih, engl. youth and brain drain), te gubitkom radne snage u pojedinim sektorima (npr., slično kao i Hrvatska, velik broj zemalja suočen je s gubitkom liječnika i medicinskih sestara zbog njihova odlaska na rad u razvijene države OECD-a). ${ }^{31}$

To sve može imati dalekosežne i višestruke nepovoljne demografske, strukturne i razvojne ishode za takva društva. Kod toga treba znati da veće gubitke po osnovi odljeva visokoobrazovne snage trpe male zemlje, jer je takav odljev proporcionalno veći u odnosu na njihovu ukupnu populaciju. ${ }^{32}$ Osim toga, gospodarski rast ovisi i o rastu stanovništva i o tehnološkom napretku. ${ }^{33}$ Stoga bi vladama, posebice u Hrvatskoj, trebale biti važne mjere usmjerene na gospodarski razvoj, demografsku pronatalitetnost, političku stabilnost i pravnu sigurnost.

\subsection{Migracije i tržište rada}

Razlike u plaći vrlo su jak pokretač mobilnosti, prema nekima jači od nezaposlenosti. ${ }^{34}$ To se odnosi i na minimalnu plaću, čija razina i promjene u visini privlače niskokvalificirane imigrante, koji najčešće i obavljaju najniže plaćene poslove. ${ }^{35}$ Međutim, uz mogućnost povećane zarade, smatramo da je potražnja za određenim zanimanjima u zemlji primateljici ključna za priljev i položaj migranata na tržištu rada.

Imigranti su tradicionalno bili niskokvalificirani radnici, koji u razvijenim poslijeindustrijskim državama obavljaju opasne, za zdravlje štetne ili neugodne poslove. Međutim, od kraja 20. st. primjetan je selektivan probir uslijed segmentiranosti i promjena na tržištu rada. Sve više nalazimo visokokvalificirane radnike. ${ }^{36}$ Zbog novih tehnologija (automatizacije, digitalizacije i biotehnolo-

31 Više vidi u: OECD (2015.), op. cit. u bilj. 23, str. 105 - 182, http://dx.doi.org/10.1787/ migr_outlook-2015-en (15. prosinca 2015.).

32 Ibid., str. 22.

33 Stopa rasta proizvodnje u ravnotežnom stanju jednaka je zbroju stope rasta stanovništva i stope rasta tehnološkog napretka. Stopa rasta nije ovisna o stopi štednje, već je stopa štednje važna samo za održavanje ravnotežnog stanja. Prema: Čavrak, op. cit. u bilj. 28, str. 119.

34 Barslund, M.; Busse, M.; Schwarzwälder, J., Labour Mobility in Europe: An untapped resource?, Centre for European Policy Studies, Policy Brief, br. 327, 2015., str. 4.

35 Giulietti, C., Is The Minimum Wage A Pull Factor For Immigrants?, Industrial and Labor Relations Review, vol. 67, br. 3, 2014., str. 649 - 674.

36 Slično vidi u: O’ Leary, op. cit. u bilj. 9, str. 390; Bejaković, op. cit. u bilj. 24, str. 98 - 99, 105.; Čavrak, op. cit. u bilj. 28, str. 118; Arslan et al., op. cit. u bilj. 10, str. 11; Canetta et al, op. cit. u bilj. 9, str. 30. 
gije), razvoja uslužnog sektora (npr. zbog turizma) te zbog povećanih potreba u zdravstvenom sektoru (npr. zbog starenja stanovništva i produženja očekivanog trajanja života) dolazi do sve veće polarizacije radnih mjesta. ${ }^{37}$ Stoga, visokoobrazovani imigranti imaju bolju poziciju na tržištu rada. Nezaposlenost među njima niža je nego za ostale radno sposobne migrante, neovisno o državi podrijetla. ${ }^{38}$ Međutim, primjetan je problem njihova prvotnog zapošljavanja na poslovima na kojima se traži niža razina obrazovanja (tzv. problem "otpada mozgova”, engl. brain waste). ${ }^{39}$

U pogledu nezaposlenosti istraživanja upućuju na zaključak da recesije neproporcionalno više pogađaju radnike migrante od domaćih radnika. To je razumljivo posebno ako migranti rade u sektorima u kojima je promjenjiva potreba za radnom snagom (tzv. ciklički sektori, kao npr. građevinarstvo) ili u sektorima koji su izloženi gospodarskoj krizi (npr. financijske i telekomunikacijske usluge u periodu nakon financijske krize 2008./2009.), pa dolazi do povratka migranata $\mathrm{u}$ njihove zemlje podrijetla. ${ }^{40}$

Osim razine obrazovanja, prisutnost imigranata u pojedinim gospodarskim sektorima blisko je povezana is njihovim podrijetlom i spolom, pa je na tržištima rada moguće identificirati procese etničke i spolne segmentacije (npr. imigranti s istoka Europe većinom rade u građevinarstvu; Kinezi, Indijci i Pakistanci $\mathrm{u}$ etničkim enklavama, posebice u ugostiteljstvu i trgovini; žene u uslužnim djelatnostima i kućanstvu). ${ }^{41}$ Ipak, u zadnje vrijeme opaža se "feminizacija migracije", posebno među visokoobrazovanim migrantima. ${ }^{42}$

\subsection{Pravni aspekti radnih migracija}

Unutar migracijskih politika uobičajilo se razlikovati imigracijske mjere, kojima se propisuje ulazak, boravak, zapošljavanje, povratak i deportacija imi-

37 Više o razvoju novih poslova vidi npr. u: WEF (2016.), The Future of Jobs: Employment, Skills and Workforce Strategy for the Fourth Industrial Revolution, World Economic Forum, 2016., http://www3.weforum.org/docs/WEF_Future_of_Jobs.pdf (8. ožujka 2016).

38 Arslan et al., op. cit. u bilj. 10, str. 33.

39 Ibid.

40 OECD (2015.), op. cit. u bilj. 23, str. 60 - 64, 77 - 80, 84; Arslan et al., op. cit. u bilj. 10 , str. 31.

41 Gregurović, S., Utjecaj eurointegracijskih procesa na migracije - lekcije za Hrvatsku, u: Puljiz, V. et al. (ur.), Migracije i razvoj Hrvatske: podloga za hrvatsku migracijsku strategiju, Hrvatska gospodarska komora, Zagreb, 2014., str. 274.

42 Arslan et al., op. cit. u bilj. 10, str. 11. 
granata, od integracijskih mjera, kojima se uređuje način uključivanja imigranata u društvo primitka. ${ }^{43}$ Postoje dva osnovna modela imigracijskih politika. Useljenički programi promiču prihvat stranih radnika s ciljem njihova dugotrajnog nastanjenja, dok su privremeni programi osmišljeni s namjerom da se migranti vrate $\mathrm{u}$ domovinu.$^{44}$ Integracijske mjere usmjerene su na uključivanje imigranata u društvo i dijele se na tzv. asimilacijske (usmjerene prema strancu i njegovoj prilagodbi društvu u koje dolazi) i pluralističke (usmjerene na izjednačavanje prava imigranata s pravima članova države primitka, uz zadržavanje prava na različitost). ${ }^{45}$

Međutim, imigrantima je za bilo kakvo ostvarivanje prava važan test zakonitog boravka (ili prebivališta), koji ima uključujući i isključujući učinak. S jedne je strane blaži uvjet od uvjeta državljanstva za ostvarivanje nekih prava, a s druge strane djeluje isključujuće za sve one koji ne ispunjavaju uvjet, kao npr. nezakoniti migranti (engl. illegal migrants, noviji pojam je irregular migrants). ${ }^{46}$ Dodatno se čak i u slučaju zakonitog boravka često radi razlika u pravima između ekonomski aktivnih osoba (radnika i samozaposlenih) od ostalih ekonomski neaktivnih osoba. To posebno dolazi do izražaja u pravu EU-a.

\section{RADNE MIGRACIJE U EU-u}

\subsection{Opće napomene}

U pravnom poretku EU-a postoje brojne odredbe primarnog i sekundarnog prava koje uređuju materiju radnih migracija. Neke od njih se odnose na državljane EU-a, a druge na državljane trećih država (imigrante izvan EU-a). Za državljane država članica EU-a i članove njihovih obitelji važne su odredbe o slobodi kretanja radnika te odredbe o slobodi pružanja usluga i poslovnog nastana. Te odredbe zajedno s odredbama o slobodnom protoku roba i kapitala čine jedinstvenu cjelinu usmjerenu na ukidanje trgovinskih prepreka i uspostavu jedinstvenog tržišta. U svojem bitnom dijelu postoje od Ugovora o osnivanju Europske ekonomske zajednice iz 1957. U okviru te pravne stečevine razlikuju se prava radnika i članova njihovih obitelji od prava tražitelja zaposlenja, sa-

43 Čačić-Kumpes, J.; Gregurović, S.; Kumpes, J., Migracija, integracija i stavovi prema imigrantima u Hrvatskoj, Revija za sociologiju, vol. 42, br. 3, 2012., str. 308.

44 Više vidi u: Skupnjak Kapić, op. cit. u bilj. 28, str. 231 - 232; Tintić, op. cit. u bilj. 3, str. $55-64$.

45 Više u: Čačić-Kumpes et al., op. cit. u bilj. 43, str. 308.

46 Vonk et al., op. cit. u bilj. 29, str. $22-23$. 
mozaposlenih osoba i upućenih radnika (radnika koji pružaju uslugu u drugoj državi članici u ime i za račun svojeg poslodavca). Poseban režim postoji za radnike iz novih država članica. Više o svemu u poglavljima koja slijede. Zbog cjelovitosti prikaza smatramo potrebnim spomenuti da ostali državljani EU-a (npr. umirovljenici, turisti itd.) uživaju pravo na slobodu kretanja i boravak u drugoj državi članici na temelju svojeg statusa građanina Unije (sada čl. 21. Ugovora o funkcioniranju EU-a ${ }^{47}$; dalje UFEU), koji je uveden Ugovorom iz Maastrichta 1992. S obzirom na to da nije riječ o radnim migrantima, njihova prava neće biti predmet analize u ovom radu.

Za ulazak, boravak i rad državljana iz trećih država (država koje nisu članice EU-a) mjerodavne su odredbe o graničnoj kontroli, azilu i useljavanju (čl. 77. 80. UFEU-a), koje su prvi put postale dio zajedničke politike EU-a Ugovorom iz Amsterdama 1997. ${ }^{48} \mathrm{Na}$ temelju tih odredbi donesen je niz uredbi i direktiva koje uređuju nadzor granica i položaj tih osoba. Premda u ovom tekstu nećemo detaljnije elaborirati o useljeničkoj politici EU-a ${ }^{49}$, ipak smatramo potrebnim spomenuti kako je u ovom području, među ostalim, doneseno i nekoliko direktiva važnih za radne migracije, kao npr.: l) direktive usmjerene na olakšano useljavanje određenih poželjnih skupina poput studenata ${ }^{50}$, znanstvenih istraživača ${ }^{51}$, visokokvalificiranih radnika ${ }^{52}$ i sezonskih radnika ${ }^{53}$, te na premještaj rukovodećih zaposlenika, stručnjaka i pripravnika unutar poduzeća ${ }^{54}, 2$ ) direktiva o izdavanju jedinstvene dozvole za boravak i $\operatorname{rad}^{55}$ te 3) direktiva koja propisuje sankcije i mjere za poslodavce koji zapošljavaju nezakonite imigrante. ${ }^{56}$ Ta činjenica dokazuje da EU na supranacionalnoj razini pokušava putem selektivne imigracijske politike riješiti svoje demografske probleme (starenje stanovništva zbog smanjenja nataliteta i produženja životnoga vijeka), kao i

47 Službeni list Europske unije, C 202, 7. lipnja 2016.

48 Te odredbe spadaju u Područje slobode, sigurnosti i pravde (glava V. UFEU-a), iz čije primjene su se izuzele UK i Irska (na temelju protokola br. 21) i Danska (na temelju protokola br. 22).

49 Više o ovoj temi vidi u: Špadina, H., Radne migracije državljana trećih država u EU: Pravni okvir, problemi i perspektive, doktorska disertacija, Sveučilište Josipa Jurja Strossmayera u Osijeku, Osijek, 2013.

50 Direktiva 2004/114/EZ.

51 Direktiva 2005/71/EZ.

52 Direktiva 2009/50/EZ.

53 Direktiva 2014/36/EU.

54 Direktiva 2014/66/EU.

55 Direktiva 2011/98/EU.

56

Direktiva 2009/52/EZ. 
kadrovsko-kvalifikacijske probleme nedostatka odgovarajuće radne snage, posebno visokokvalificiranih osoba. ${ }^{57}$

\subsection{Sloboda kretanja radnika u EU-u}

\subsubsection{Pravni okvir}

Politika EU-a u području slobode kretanja radnika odnosi se na osobe u radnom odnosu (dakle osobe koje obavljaju tzv. ovisan, nesamostalan rad), tražitelje zaposlenja te članove njihovih obitelji. Usmjerena je $s$ jedne strane na ukidanje prepreka (čl. 45. - 48. UFEU-a), a s druge strane na olakšavanje migracijskih tokova između država članica putem instrumenata unifikacije (uredbe) i harmonizacije (direktive). Važniji sekundarni izvori prava u ovom području mogu se grupirati u 4 skupine: 1) propise koji uređuju slobodu kretanja i ostvarivanje prava na boravak na državnom području druge države članice, pristup zaposlenju i jednako postupanje $\left.{ }^{58}, 2\right)$ propise koji sprečavaju gubitak socijalnih prava (među kojima su najvažnije uredbe o koordinaciji sustava socijalne sigurnosti) $^{59}$, 3) propise koji se odnose na obrazovanje djece migranata ${ }^{60}$ i 4) propise koji se odnose na priznavanje kvalifikacija. ${ }^{61}$ Posebno važan doprinos u razvoju pravnih aspekata slobode kretanja ima i Sud EU-a.

Također je važno spomenuti da se pravna stečevina u području slobode kretanja radnika primjenjuje na sve radne odnose i profesionalne aktivnosti s

57 Vukorepa, I., Sloboda kretanja radnika u Europskoj uniji, Godišnjak Tribine Pravnog fakulteta Sveučilišta u Zagrebu i Kluba pravnika Grada Zagreba, Pravni fakultet Sveučilišta u Zagrebu, Zagreb, 2013., str. 37 - 38. Slično vidi i u: Davies, A., EU Labour Law, Edward Elgar, Cheltenham, 2012., str. 103 - 104.

58 Uredba 492/2011 o slobodi kretanja radnika; Direktiva 2004/38/EZ o pravima građana Unije; Direktiva 2014/54/EU o mjerama za lakše ostvarivanje prava na slobodu kretanja radnika; Uredba (EU) 2016/589 o Europskoj mreži službi za zapošljavanje (EURES), pristupu radnika uslugama mobilnosti i daljnjoj integraciji tržišta rada; Uredba (EU) 2016/1191 o promicanju slobodnog kretanja građana pojednostavnjenjem zahtjeva za predočavanje određenih javnih isprava.

59 Uredba (EZ) br. 883/2004 o koordinaciji sustava socijalne sigurnosti; Uredba (EZ) br. 987/2009 o utvrđivanju postupka provedbe Uredbe (EZ) br. 883/2004 o koordinaciji sustava socijalne sigurnosti; Direktiva 98/49/EZ o zaštiti prava na dopunsku mirovinu zaposlenih i samozaposlenih osoba koje se kreću unutar Zajednice; Direktiva 2014/50/EU o minimalnim zahtjevima za poboljšanje mobilnosti radnika među državama članicama unaprjeđivanjem stjecanja i očuvanja prava na dopunsku mirovinu.

60 Direktiva 1977/486/EEZ. Također i čl. 10. Uredbe (EU) br. 492/2011.

61 Direktiva 2005/36/EZ. 
elementom inozemnosti između država članica Europskog ekonomskog prostora (dalje EGP), ${ }^{62}$ djelomično na Švicarsku te prekomorske teritorije pojedinih država članica EU-a. ${ }^{63}$ Primjenjuje se čak i na radne odnose koji se obavljaju izvan teritorija EGP-a ako je ugovor o radu blisko vezan uz neku državu članicu. ${ }^{64}$

\subsubsection{Pojam "radnik"}

Od samog početka nametnulo se pitanje koji je krug osoba zaštićen pojmom "radnik" u kontekstu slobode kretanja. Sud EU-a naglasio je da odluku treba donijeti u svjetlu pravnog poretka EU-a, a ne samo primjenjujući nacionalne kriterije. ${ }^{65}$ Posljedično, široko je definirao pojam radnika, naglašavajući njegovu ekonomsku i socijalnu dimenziju. Slijedom sudske prakse sloboda kretanja radnika odnosi se na sve osobe koje obavljaju bilo koju vrstu ekonomske aktivnosti, bez obzira na to jesu li one $u$ formalnom radnom odnosu ili nisu. ${ }^{66}$ Važna je također prisutnost elemenata subordinacije i naplatnosti ${ }^{67}$, ali je pritom nebitno je li plaća u novcu ili naravi. ${ }^{68}$ Nadalje, pravila o slobodi kretanja radnika odnose se i na osobe koje rade $u$ nepunom radnom vremenu bez obzira na iznos novca koji tako zarade ${ }^{69}$ te njihovoj eventualnoj dodatnoj potrebi za primanjem socijalne pomoći. $^{70}$ Također, primjenjuju se i na radnike na određeno vrijeme ${ }^{71}$, radnike po pozivu (engl. on-call contract) ${ }^{72}$, vježbenike ${ }^{73}$ te sportaše $^{74}$. Slijedom dosadašnje

62 EGP čine države članice EU-a te Island, Lihtenštajn i Norveška.

63 Npr. na Guadeloupe, Francusku Gvajanu, Martinik, Reunion, Saint-Barthelemy, Saint-Martin, Azore, Madeiru i Kanarske otoke itd. Više vidi u čl. 355. UFEU-a.

C-214/94 od 30. travnja 1996., Boukhalfa / Bundesrepublik Deutschland, ECLI:EU:C:1996:174.

65 C-75/63 od 19. ožujka 1964. Hoekstra, ECLI:EU:C:1964:19.

66 C-36/74 od 12. prosinca 1974. Walrave and Koch, ECLI:EU:C:1974:140; C-196/87 od 5. listopada 1988., Steymann, ECLI:EU:C:1988:475.

C-66/85 od 3. srpnja 1986., Lawrie-Blum, ECLI:EU:C:1986:284, para. 17.

C-53/81 od 23. ožujka 1982., Levin, ECLI:EU:C:1982:105.

C-139/85 od 3. lipnja 1986., Kempf, ECLI:EU:C:1986:223.

C-413/01 od 6. studenoga 2003., Ninni Orasche, ECLI:EU:C:2003:600.

C-357/89 od 26. veljače 1992., Raulin, ECLI:EU:C:1992:87.

C-3/90 od 26. veljače 1992., Bernini, ECLI:EU:C:1992:89.

Vidi npr. C- 36/74 od 12. prosinca 1974. Walrave and Koch, ECLI:EU:C:1974:140; C-415/93 od 15. prosinca 1995., Bosman, ECLI:EU:C:1995:463; C-325/08 od 16. ožujka 2010., Olympique Lyonnais / Bernard, ECLI:EU:C:2010:143. 
ustaljene sudske prakse možemo očekivati da će Sud EU-a u kontekstu slobode kretanja radnika i ubuduće zauzimati široki interpretativni stav u odnosu na nove i sve češće atipične oblike rada (npr. povremeni rad, rad putem vrijednosnog kupona, rad bez ugovorene satnice itd.), premda kod takvih poslova, posebice između dvaju poslova, može postojati dvojba o tome je li riječ o radnicima ili tražiteljima posla. ${ }^{75}$ Distinkcija između radnika i tražitelja zaposlenja važna je jer ima za posljedicu različitu razinu u pravima (više u poglavljima koja slijede).

Naime, da bi osoba bila obuhvaćena pojmom "radnik" u smislu prava EUa, mora biti riječ o ekonomskoj aktivnosti koja se može smatrati "istinitom i učinkovitom" (engl. genuine and effective work) ${ }^{76}$, odnosno "stvarnom i pravom" (engl. real and genuine activity) $)^{77}$, jer propisi EU-a ne pokrivaju aktivnosti vrlo malog opsega ako su one marginalne i pomoćne (engl. marginal and ancillary). ${ }^{78}$ U tom smislu osobe koje obavljaju rehabilitacijski rad ili su uključene u radne programe reintegracije u društvo u pravilu nisu radnici u smislu prava EU-a. ${ }^{79}$ Međutim, osobe s invaliditetom zaposlene u posebnim radionicama mogu biti obuhvaćene pojmom "radnik" 80 ako takav rad (socijalno-zaštitnog karaktera) ima određenu ekonomsku korisnost ${ }^{81}$ i pod uvjetom da se poslovi koje osoba stvarno obavlja mogu smatrati dijelom normalnog tržišta rada. ${ }^{82}$

\subsubsection{Temeljna prava radnika i članova obitelji}

Većina osoba želi potpasti pod pojam "radnik" u smislu prava EU-a s obzirom na to da im to osigurava širi krug prava od onih koja se izvode iz statusa građanina Unije ili tražitelja zaposlenja. Temeljne odredbe koje jamče slobodu

75 Vidi i O’Brien, C.; Spaventa, E.; De Coninck, J., Comparative Report 2015: The concept of worker under Article 45 TFEU and certain non-standard forms of employment, European Commission, Brussels, 2016.

76 C-53/81 od 23. ožujka 1982., Levin, ECLI:EU:C:1982:105., para. 17.

77 C-456/02 od 7. rujna 2004., Trojani, ECLI:EU:C:2004:488, para. 17, 29.

78 Sud EU-a, C-53/81 od 23. ožujka 1982., Levin, ECLI:EU:C:1982:105., para. 17. Također vidi C-413/01 od 6. studenoga 2003., Ninni Orasche, ECLI:EU:C:2003:600.

79 C-344/87 od 31. svibnja 1989., Bettray, CLI:EU:C:1989:226. Također vidi C-456/02 od 7. rujna 2004., Trojani, ECLI:EU:C:2004:488.

80 C-316/13, Fenoll od 26. ožujka 2015., EU:C:2015:200.

81 Ibid., para 40.

82 U tu svrhu mogu se uzeti u obzir ne samo status i praksa takve ustanove već i različiti aspekti ciljeva takvog specifičnog programa socijalne skrbi te priroda i načini obavljanja poslova (ibid., para. 42.). 
kretanja radnika unutar EU-a propisane su čl. 45. UFEU-a te se ne odnose na poslove s javnim ovlastima (o čemu će više biti riječi u poglavlju 3.2.5. Iznimke od slobode kretanja). Sud EU-a, naglašavajući njihovu važnost, utvrdio je da one imaju izravan učinak, i to vertikalan i horizontalan. ${ }^{83}$ Propisano je da sloboda kretanja podrazumijeva "ukidanje svake diskriminacije temeljem državljanstva među radnicima iz država članica u vezi sa zapošljavanjem, primicima od rada i ostalim uvjetima rada i zapošljavanja". ${ }^{84}$ Dakle, radnik migrant iz bilo koje države članice EU-a i EGP-a treba imati ista prava kao i usporedivi domaći radnik. ${ }^{85}$ Sekundarni izvori propisuju da se to posebice odnosi na stručno usavršavanje, socijalne povlastice, stambeno zbrinjavanje i porezne olakšica te članstvo $u$ sindikatu ${ }^{86}$, kao i na pravo na socijalnu pomoć čak i tijekom prvih triju mjeseci boravka u državi primateljici. ${ }^{87}$ Iznimno, primjenjujući načelo razmjernosti i primjerenosti, znanje određenog jezika može se tražiti kao uvjet za zaposlenje zbog specifične prirode i potrebe posla. ${ }^{88}$

Nadalje, sukladno čl. 45. st. 3. UFEU-a sloboda kretanja radnika obuhvaća sljedeća prava: 1) pravo na prihvaćanje stvarno učinjenih ponuda za zaposlenje, 2) pravo na slobodno kretanje unutar područja država članica u svrhu zapošljavanja, 3) pravo na boravak u državi članici radi zapošljavanja sukladno odredbama o zapošljavanju državljana te države predviđenih zakonom i drugim propisom (slijedom navedenog radne dozvole, kao preduvjet za zakonito zaposlenje, nisu dopuštene $)^{89}$ te 4) pravo na ostanak na području države članice nakon prestanka zaposlenja u toj državi, pod uvjetima sadržanim u provedbenim propisima EUa. ${ }^{90}$ Iznimno, ta je sva prava moguće ograničiti razlozima javnog poretka, javne

83 Vukorepa, I., Sloboda kretanja osoba, u: Mintas-Hodak, Lj. (ur.), Uvod u Europsku uniju, Mate d.o.o., Zagreb, str. 129 - 130).

Čl. 45. st. 2. UFEU-a.

85 Više o zabrani izravne i neizravne diskriminacije vidi u: Barnard, C., EU Employment Law, Oxford University Press, Oxford, 2012., str. 159 - 161. Također vidi Van Overmeiren, F.; O’Brien, C.; Spaventa, E.; Jorens, Y.; Schulte, B., Analytical Report 2014. The notion of obstacle and discrimination under EU law on free movement of workers, FreSsco, European Commission, December 2014.

Čl. 7. i 8. Uredbe 492/2011.

Čl. 3. st. 1. podstavak 2. Uredbe (EU) br. 492/2011. Vidi i C- 379/87 od 28. studenoga 1989., Groener, ECLI:EU:C:1989:599; C-281/98 od 6. lipnja 2000., Angonese, ECLI:EU:C:2000:296.

Međutim, dozvoljena je registracija iz statističkih razloga.

90 Pravo na stalni boravak i prije isteka razdoblja od pet godina zakonitog boravka imaju radnici i samozaposleni koji su prestali raditi npr. zbog 1) navršenja dobi 
sigurnosti ili javnog zdravlja. ${ }^{91}$ Direktiva 2004/38 detaljnije propisuje uvjete za različitu duljinu prava na boravak, pa tako razlikujemo: 1) boravak do tri mjeseca, 2) boravak dulji od tri mjeseca te 3) stalni boravak (nakon neprekinutog razdoblja od pet godina zakonitog boravka).

Članovi obitelji radnika migranta uživaju komplementarna prava (pravo na ulazak, boravak i rad ili samozapošljavanje, stručno usavršavanje, a djeca na školovanje i stipendije).$^{92}$ Ako je član obitelji ujedno i državljanin neke od država članica EGP-a, tada on ima i samostalna prava koja izvodi iz statusa građanina Unije; a ako je riječ o državljaninu neke treće države, onda njegova prava proizlaze iz obiteljske povezanosti s radnikom migrantom. Članovi obitelji sukladno čl. 2. st. 2. Direktive 2004/38 jesu supružnici, registrirani partneri (ali samo ako država primateljica u svojoj državi dozvoljava registrirano partnerstvo), nadalje srodnici radnika te njegova bračnog druga ili partnera po krvi u uspravnoj liniji nishodno, do navršene 21. godine života, srodnici po krvi u uspravnoj liniji ushodno, koje je radnik ili njegov bračni drug odnosno partner dužan uzdržavati i stvarno ih uzdržava. Međutim, čl. 3. st. 2. Direktive 2004/38 propisujući obvezu "olakšanog ulaska i boravka" proširuje taj krug osoba na partnere koji žive u trajnoj vezi te ostale članove obitelji ako ih radnik migrant uzdržava ili žive u zajedničkom kućanstvu ili im je potrebna njega uslijed ozbiljnih zdravstvenih razloga.

Nadalje, u slučaju smrti radnika migranta ili razvoda braka (također i poništenja braka ili prestanka registriranog partnerstva) članovi obitelji zadržavaju pravo na boravak, premda se opseg prava i uvjeti razlikuju s obzirom na podrijetlo člana obitelji. Naime, navedene okolnosti ne utječu na pravo na boravak članova obitelji koji su ujedno i sami državljani jedne od država članica EU-a, dok članovi obitelji iz trećih država moraju ispunjavati određene uvjete, npr. prethodni boravak u državi članici domaćinu najmanje godinu dana u svojstvu člana obitelji umrloga građanina EU-a; brak u trajanju od najmanje tri godine

za starosnu ili prijevremenu starosnu mirovinu, a prethodno su radili najmanje 12 mjeseci i neprekidno boravili u državi članici domaćinu tri godine, ili 2) trajne nesposobnosti za rad, a neprekidno su boravili u državi članici domaćinu najmanje dvije godine itd. Više vidi u čl. 17. Direktive br. 2004/38/EZ.

91 Više vidi infra u poglavlju 3.2.5. Iznimke od slobode kretanja.

92 Vidi čl. 6., 7. st. 2., 17. st. 3. i 4., 23. i 24. Direktive br. 2004/38/EZ i čl. 10 Uredbe (EU) br. 492/2011. Pravo na socijalne povlastice (stipendije za studiranje) imaju i djeca pograničnih radnika (vidi presude: C-238/15, od 14. prosinca 2016., Branganca Linares Verruga and Others, ECLI:EU:C:2016:949, i združene slučajeve C-401/15, C-402/15, C-403/15 Depesme and Kerrou, od 15. prosinca 2016. ECLI:EU:C:2016:955). 
uz uvjet boravka od najmanje godinu dana u državi članici domaćinu prije pokretanja postupka razvoda ili poništenja braka itd. ${ }^{93}$

Međutim, ovdje treba upozoriti i na noviju sudsku praksu. Sukladno predmetu Singh i dr., ako prije razvoda braka bračni drug koji je građanin EU-a napusti državu članicu u kojoj su zajednički živjeli, tada državljanin iz treće države članice ne zadržava pravo na boravak. ${ }^{94}$ Smatramo da je takvo pravno shvaćanje u skladu sa propisima EU-a jer su prava članova obitelji iz trećih država izvedena iz prava radnika migranata građana EU-a. Ipak, puno obazrivije pravno razmatranje Sud primjenjuje ako par ima dijete. Zbog zaštite interesa dijeta, a uzimajući u obzir sve okolnosti slučaja, državljanin zemlje izvan EU-a može se kao roditelj maloljetnog djeteta pozvati na izvedeno pravo na boravak u Uniji. Prema presudi NA dijete i roditelj državljanin treće države koji ima samostalno pravo na njegovo čuvanje i odgoj imaju pravo boravka u državi članici domaćinu u situaciji u kojoj je drugi roditelj građanin EU-a prestao boraviti u državi članici u kojoj je radio prije nego što je dijete ondje započelo školovanje. ${ }^{95} \mathrm{U}$ presudi Chavez-Vilchez $i$ dr. odlučeno je da je okolnost da drugi roditelj, građanin EU-a, može preuzeti svakodnevnu i stvarnu brigu o djetetu, važan čimbenik za odlučivanje o pravu na dozvolu boravka razvedenog roditelja iz treće zemlje, ali sam po sebi nije dovoljan za odbijanje dozvole. Sud EU-a upozorava na to da je kod odlučivanja potrebno utvrditi postoji li između djeteta i roditelja državljanina treće zemlje takav odnos ovisnosti zbog kojeg bi u slučaju odbijanja prava na boravak dijete moralo napustiti područje EU-a. Kod toga treba uzeti u obzir sve okolnosti slučaja, a osobito djetetovu dob, fizički i emocionalni razvoj, stupanj emocionalne povezanosti i s roditeljem građaninom Unije is roditeljem državljaninom treće zemlje, kao i rizike koji bi mogli nastati za stabilnost tog djeteta u slučaju razdvajanja od potonjeg roditelja. ${ }^{96}$

\subsubsection{Prava tražitelja zaposlenja i osoba koje zadržavaju status radnika}

Iz odredbe čl. 45. UFEU-a proizlazi da tražitelji zaposlenja imaju pravo na slobodu kretanja i pravo na boravak u drugoj državi članici u svrhu zapošljavanja. Međutim, sporna je dužina prava na boravak tih osoba. U skladu s presudom u slučaju Antonissen ${ }^{97}$, Direktiva 2004/38/EZ propisuje ograničeno

\footnotetext{
93 Više vidi u čl. 12. i 13. Direktive br. 2004/38/EZ.

94 C-218/14 od 16. srpnja 2015., Singh i dr., ECLI:EU:C:2015:476.

95 C-115/15 od 30. lipnja 2016., NA, ECLI:EU:C:2016:487.

96 C-133/15 od 10. svibnja 2017., Chavez-Vilchez i dr., ECLI:EU:C:2017:354.

97

C-292/89 od 26. veljače 1991. The Queen v. Antonissen, ECLI:EU:C:1991:80.
} 
trajanje prava na boravak u svrhu zapošljavanja: bezuvjetno pravo boravka do tri mjeseca ${ }^{98}$, uz indirektnu mogućnost produženja putem odredbi o zabrani protjerivanja toliko dugo dok tražitelj zaposlenja može dokazati da i dalje traži posao i da ga ima stvarne izglede naći. ${ }^{99}$ Smatramo da bi to bio npr. slučaj u kojem tražitelj zaposlenja ima dokaze o slanju molbi za zaposlenje, čeka poziv na razgovor itd. Tražitelji zaposlenja osim prava na boravak imaju, po prirodi stvari, pravo na pristup zaposlenju, te u tom slučaju dalje ostvaruju prava kao radnici migranti.

Članak 24. st. 2. Direktive ograničava pravo na jednako postupanje proklamirano u st. l. istog članka jer je propisano da osobe koje borave do tri mjeseca kao i tražitelji zaposlenja nemaju pravo na socijalnu pomoć. Time se želi izbjeći da građani Unije koji su državljani drugih država članica postanu neprimjeren teret za sustav socijalne skrbi države članice domaćina. Ipak, u praksi su se javile dvojbe oko prava na novčanu pomoć u svrhu zapošljavanja. Stoga pri tumačenju opsega socijalnih prava tražitelja zaposlenja Sud EU-a pravi razliku s obzirom na svrhu pojedinog socijalnog davanja. Tako tražitelj zaposlenja ima mogućnost ostvarivanja prava na novčanu pomoć za olakšavanje traženja zaposlenja na tržištu rada države članice domaćina pod uvjetom da je stvarno i povezan $s$ tržištem rada dotične države (npr. da je određeno vrijeme tražio posao). ${ }^{100}$ Međutim, Sud EU-a odriče tražiteljima zaposlenja pravo na socijalnu pomoć, uključujući i nedoprinosna davanja kojima je namjena osiguranje osnovnih životnih troškova potrebnih za život dostojan čovjeka. ${ }^{101}$

Postoje i osobe koje više nisu formalno radnici (niti su samozaposlene osobe), ali kroz određeno vrijeme i pod određenim propisanim okolnostima zadržavaju status radnika, pa time i pravo na boravak dulji od tri mjeseca i ostala pripadajuća

98 Čl. 6. Direktive 2004/38/EZ.

99 Čl. 14. st. 4 (b) Direktive 2004/38/EZ.

${ }^{100}$ C-22/08 i C-23/08 od 4. lipnja 2009., Vatsourasi Koupatantze, ECLI:EU:C:2009:344., para. 37 - 42, 45. Vidi i starije presude, npr. C-258/04 od 15. rujna 2005., Ioannidis, EU:C:2005:559 (posebno para. 22).

${ }_{101}$ C-67/14 od 15. rujna 2015., Alimanovic, EU:C:2015:597, para 45, 46, 50. Također vidi slične isključujuće presude za ekonomski neaktivne osobe (C 140/12 Brey, od 19. rujna 2013., EU:C:2013:965, C-333/13 od 11. studenoga 2014., Dano, ECLI:EU:C:2014:2358; C-299/14 od 25. veljače 2016., Garcia-Nieto i drugi, ECLI:EU:C:2016:114), odnosno osobe koje nemaju zakonito pravo boravka (npr. C-308/14 od 14. lipnja 2016., Komisija / Ujedinjena Kraljevina, ECLI:EU:C:2016:436). 
prava (npr. pravo na socijalnu pomoć). ${ }^{102}$ To su u skladu s čl. 7. st. 3. Direktive 2004/38 sljedeće osobe: 1) osoba privremeno nesposobna za rad zbog bolesti ili nesreće, 2) nesvojevoljno nezaposlena osoba prijavljena kao tražitelj zaposlenja u nadležnom uredu za zapošljavanje (kod kojih osoba se dužina boravka razlikuje ovisno o tome koliko je dugo osoba prethodno radila; ako je radila dulje od godinu dana, onda bez navođenja minimuma i maksimuma; a ako je radila kraće od godinu dana, tada zadržava status radnika tijekom najmanje šest mjeseci) ${ }^{103}$ i 3) osoba koja je započela strukovno osposobljavanje, pod uvjetom da postoji veza između osposobljavanja i prethodnog zaposlenja, a koji uvjet se ne traži u slučaju da je osoba ostala nesvojevoljno nezaposlena. Nadalje, u predmetu Saint Prix sud je to pravo na zadržavanje statusa radnika proširio i na ženu koja prestaje raditi ili tražiti posao zbog tjelesnih ograničenja povezanih s poodmaklom trudnoćom ili posljedicama poroda, pod uvjetom da se vrati na posao ili pronađe novi u razumnom vremenu nakon rođenja djeteta. ${ }^{104}$

\subsubsection{Iznimke od slobode kretanja}

Analizirajući odredbu čl. 45. Ugovora o funkcioniranju EU-a te sudsku praksu Suda EU-a možemo zaključiti da postoje tri glavne grupe iznimaka od slobode kretanja radnika. To su: 1) zapošljavanje na određenim poslovima u javnoj službi, 2) zaštita javnog poretka, javne sigurnosti i javnog zdravlja te 3) zaštita drugih opravdanih interesa. Kod tumačenja većine iznimki Sud EU-a naglašava i primjenjuje restriktivni pristup.

Osim toga, na temelju odredbi ugovora o pristupanju novih država članica važnu četvrtu iznimku čine odredbe o kontroli priljeva radne snage iz novih država članica za vrijeme prijelaznog razdoblja, o čemu će biti više riječi u posebnom poglavlju, jer se te odredbe djelomično odnose i na slobodu pružanja usluga putem upućenih (izaslanih) radnika. ${ }^{105}$

102 Sukladno čl. 24. st. 2. Direktive 2004/38/EZ radnici, samozaposlene osobe, osobe koje zadržavaju taj status, kao i članovi njihove obitelji imaju pravo na socijalnu pomoć i pomoć za uzdržavanje u svrhu školovanja tijekom cijelog razdoblja boravka u drugoj državi članici, dakle i tijekom prvih triju mjeseci.

103 Sukladno presudi C-292/89 od 26. veljače 1991. The Queen v. Antonissen, ECLI:EU:C:1991:80.

104 C-507/12 od 19. lipnja 2014., Saint Prix, ECLI:EU:C:2014:2007, vidi t. 41. - 47.

105 Više vidi u poglavlju 3.3. Prijelazna režim za državljane iz novih država članica. 


\subsubsection{Javna služba}

Sukladno čl. 45. st. 4. UFEU-a odredbe o slobodi kretanja radnika ne primjenjuju se na javnu službu. Prema praksi Suda EU-a pod tu iznimku potpadaju samo ona radna mjesta koja "uključuju neposredno ili posredno sudjelovanje u obavljanju javnih ovlasti i dužnosti koje imaju za cilj zaštitu općeg interesa države ili nekih drugih područja javne vlasti". ${ }^{106}$ Premda iz dikcije presude nije jasno je li riječ o alternativno ili kumulativno postavljenim zahtjevima, općenito se smatra da oba uvjeta moraju biti kumulativno zadovoljena, tj. da je riječ o radnom mjestu koje: l) uključuje neposredno ili posredno sudjelovanje u obavljanju javnih ovlasti te 2) uključuje dužnosti koje imaju za cilj zaštitu općeg interesa države ili nekih drugih područja javne vlasti. ${ }^{107}$ Sud dakle zanemaruje institucionalni pristup i naglašava funkcionalni pristup u procjeni radnog mjesta koje se želi podvesti pod iznimku. ${ }^{108}$

Prema sadašnjem stanju propisa hrvatsko državljanstvo u pravilu je uvjet za zapošljavanje na radna mjesta državnih službenika (ne i namještenika) u državnoj službi te na radna mjesta službenika i namještenika u lokalnoj i područnoj (regionalnoj) samoupravi. Međutim, i na ta radna mjesta moguće je zaposliti osobe koje su strani državljani i osobe bez državljanstva, pod uvjetom da osim ispunjavanja uvjeta propisanih posebnim zakonom (Zakonom o strancima) postoji i prethodno odobrenje središnjeg tijela državne uprave nadležnog za službeničke odnose (Ministarstvo uprave). ${ }^{109} \mathrm{~S}$ obzirom na prethodno opisanu pravnu stečevinu EU-a, naglašavamo da je kod davanja takvog odobrenja potre-

106 C-149/79 od 17. prosinca 1980., Komisija / Belgija (br. 1) ECLI:EU:C:1980:297, t. 10. Također vidi C-149/79 od 26. svibnja 1982., Komisija / Belgija (br.2), ECLI:EU:C:1982:195; C-225/85 od 16. lipnja 1987., Komisija/ Italija, ECLI:EU:C:1987:284.

107 Vidi Craig P.; De Burca G., EU Law - Texts, cases and materials, 5. izdanje, Oxford University Press, New York, 2011., str. 736 - 737. Cf. Barnard, op. cit. u bilj. 85, str. 179. (Barnard se priklanja kumulativnoj interpretaciji, ali upozorava i na mogućnost interpretacije u smislu alternativno postavljenih zahtjeva koja proizlazi iz presude C-225/85 Komisija v. Italija).

108 Vidi također izvješcee: Ziller, J., Free Movement of European Union Citizens and Employment in the Public Sector, European Commission, 2010., Part I-General Report: http://ec.europa.eu/social/BlobServlet?docId=6401\&langId=en (25. rujna 2015.).

109 Čl. 48. st. 2. Zakona o državnim službenicima (Narodne novine, br. 92/2005, 142/2006, 77/2007, 127/2007, 27/2008, 34/2011, 49/2011, 150/2011, 34/2012, 49/2012, 37/2013, 38/2013, 1/2015, 138/2015, 61/2017) i čl. 12. st. 4. Zakona o službenicima i namještenicima u lokalnoj i područnoj (regionalnoj) samoupravi (Narodne novine, br. 86/2008, 61/2011, 4/2018). 
ban poseban oprez, te bi nadležne vlasti odluku o dozvoli zapošljavanja trebale donijeti ovisno o prirodi posla i ovlastima vezanima uz svako pojedino radno mjesto na koje se stranac koji je državljanin EGP-a želi zaposliti.

Nadalje, važno je istaknuti da posljednjih godina Sud EU-a sve više "sužava" manevarski prostor država članica da u državnom i javnom sektoru zadrži mogućnost zapošljavanja samo vlastitih državljana. Najbolji primjer za to je niz presuda iz 2011. godine u kojima je Sud EU-a ${ }^{110}$ presudio da ni javni bilježnici ne potpadaju pod iznimku od prava poslovnog nastana povezanu s izvršavanjem javnih ovlasti (čl. 5l. UFEU-a), čak ni kada djeluju kao posebni povjerenici suda u određenim postupcima (npr. ovršnom ili ostavinskom) jer je u tim slučajevima zajamčena sudska kontrola. ${ }^{111}$ Drugi primjer uskog tumačenja iznimke odnosi se na presude u vezi s kapetanima brodova, čak i kada imaju javne ovlasti na brodu (poput prava na ograničenje slobode kretanja, lišavanje slobode, bilježenje činjenica rođenja i smrti, primanje nasljednih izjava) ako te ovlasti izvršavaju neredovito i u manjem opsegu. ${ }^{112}$

Također treba naglasiti da je Sud EU-a tijekom 2016. zauzeo stav da službenici koji odluče napustiti službu radi zapošljavanja u drugoj državi članici ne smiju ni na koji način biti tretirani drukčije u vezi s njihovim mirovinskim pravima (posebno ako za njih postoji poseban službenički sustav) od osoba koje unatoč promjeni poslodavca ostaju raditi u toj državi članici. ${ }^{113}$

110 Presude Suda EU-a odnosile su se na sporove Europske komisije protiv Austrije, Belgije, Njemačke, Francuske, Grčke i Luksemburga (C-47/08, 50/08, 51/08, 53/08, 54/08, 61/08).

111 Republika Hrvatska usklađena je od 1. siječnja 2017. s tim pravnim shvaćanjem (Zakon o izmjeni Zakona o javnom bilježništvu, Narodne novine, br. 120/2016).

112 VidiC-405/01 od30.rujna2003.,ColegiodeOficiales dela Marina MercanteEspañola, ECLI:EU:C:2003:515; C-47/02 od 30. rujna 2003., Anker i dr., ECLI:EU:C:2003:516; C-460/08, 10. prosinca 2009., Komisija/Grčka, ECLI:EU:C:2009:774; C-94/08 od 20. studenoga 2008., Komisija/Španjolska, ECLI:EU:C:2008:648; C-89/07 od 11. ožujka 2008., Komisija/Francuska, ECLI:EU:C:2008:154. Republika Hrvatska je izmjenama i dopunama Pomorskog zakonika iz 2015. brisala uvjet hrvatskog državljanstva za zapovjednike brodova (vidi čl. 25., kojim su brisani čl. 146. st. 2. i 5., Narodne novine, br. 26/2015).

113 C-515/14 - Commission v Cyprus, 21. siječnja 2016., ECLI:EU:C:2016:30 i C-187/15 od 13. srpnja 2016., Pöpperl, ECLI:EU:C:2016:550. 


\subsubsection{Zaštita javnog poretka, javne sigurnosti i javnog zdravlja}

Kao što je već spomenuto, prava vezana za slobodu kretanja radnika moguće je ograničiti zbog zaštite javnog poretka, javne sigurnosti ili javnog zdravlja, ali se na te razloge ne može pozvati u gospodarske svrhe. ${ }^{114}$ Prijetnja tom zaštićenom javnom dobru mora biti stvarna i ozbiljna, a mjera s kojom se ograničava sloboda mora biti u skladu s načelom razmjernosti (koristi se još i "proporcionalnost", engl. principle of proportionality, njem. Verhältnismässigkeitsprinzip). ${ }^{115}$ Smatramo da test razmjernosti u sebi uključuje tri podtesta. Prvo, mjera mora biti prikladna za zaštitu cilja (javnog dobra koje je dopušteno štititi). Drugo, mjera mora biti nužna za postizanje tog cilja, i treće, mjera ne smije biti prekomjerna, već razmjerna dobru koje se tom mjerom želi zaštititi i zajedničkom interesu EU-a koje se tom mjerom narušava. ${ }^{116}$ Dakle, mjera kojom se ograničava sloboda kretanja radnika morala bi biti najblaža moguća mjera i samo primjenjiva ako postoji slična represivna mjera u odnosu na vlastite državljane. ${ }^{117}$

Nadalje, mjere ograničenja prava na ulazak i boravak poduzete zbog zaštite javnog poretka ili javne sigurnosti moraju se temeljiti isključivo na osobnom ponašanju pojedinca. ${ }^{118}$ Postojanje ranije kaznene osude samo po sebi nije razlog za poduzimanje takvih mjera. Osobno ponašanje dotičnog pojedinca mora predstavljati stvarnu, trenutačnu i dostatno ozbiljnu prijetnju koja utječe na neki od temeljnih interesa društva. Obrazloženja koja nisu povezana s pojedinačnim slučajem ili se odnose na opću prevenciju nisu prihvatljiva. ${ }^{119}$ Prije donošenja odluke o protjerivanju zbog razloga javnog poretka ili javne sigurnosti, država članica domaćin mora uzeti u obzir činjenice kao što su duljina boravka pojedinca na njezinu državnom području, dob, zdravstveno stanje, obiteljske i ekonomske prilike, stupanj socijalne i kulturne integracije, te opseg veza sa zemljom podrijetla. ${ }^{20}$

114 Čl. 45. st. 3. UFEU-a i čl. 27. st. 1. Direktive 2004/38.

115 Čl. 27. st. 2. Direktive 2004/38. Premda bi možda u duhu hrvatskog jezika bolji naziv bio "test primjerenosti”, engleski i njemački pojmovi upućuju na adekvatnost prijevoda "razmjernost", iako se u prijevodima Direktive 2004/38 koristi strana riječ "proporcionalnost".

116 Slično vidi i u: Van Overmeiren et al. op. cit. u bilj. 85, str. 28 - 30.

117 Vidi npr. C-115 i 116/81 od 18. lipnja 1982., Adoui i Cornuaille / Belgija, ECLI:EU:C:1982:183.

118 C-36/75 od 28. listopada 1975., Rutili, ECLI:EU:C:1975:137.

119 Čl. 27. st. 2. Direktive 2004/38.

${ }^{120}$ Više vidi u čl. 28. Direktive 2004/38. 
Mjere poduzete radi zaštite javnog zdravlja opravdane su jedino u slučaju potencijalno epidemioloških bolesti (utvrđenih mjerodavnim instrumentima Svjetske zdravstvene organizacije) te drugih zaraznih bolesti, ako protiv tih bolesti država članica domaćin donosi mjere za zaštitu svojih državljana. Bolesti koje su se pojavile nakon razdoblja od tri mjeseca od dana dolaska $u$ državu članicu nisu opravdani razlog za protjerivanje s državnog područja, a dopušteno je provoditi liječničke preglede unutar tri mjeseca, koji ne bi smjeli biti rutinski. ${ }^{121}$ Smatramo da takvo ograničenje u provođenju pregleda može biti praktičan problem kod sprečavanja širenja zaraznih bolesti.

\subsubsection{Zaštita drugih opravdanih interesa}

Tu skupinu iznimaka razvila je sudska praksa za dvije skupine mjera: 1) mjere koje su neizravno (indirektno) diskriminirajuće i 2) tzv. nediskriminatorne mjere koje mogu imati ograničavajući učinak na pravo na slobodu kretanja. ${ }^{122}$ Obje te vrste mjera moguće je opravdati pod uvjetom načela razmjernosti, a zbog zaštite nekih legitimnih ciljeva, npr. zbog zaštite potrošača, koherentnosti poreznog sustava $^{123}$, očuvanja financijske ravnoteže sustava socijalnog osiguranja odnosno socijalne sigurnosti ${ }^{124}$, sprečavanja socijalnog dampinga putem zloupotrebe prava na slobodu pružanja usluga ${ }^{125}$ itd. ${ }^{126}$

\subsection{Upućeni radnici i sloboda pružanja usluga}

Rad samozaposlenih osoba u okviru EU-a uređen je pravom na slobodu poslovnog nastana ${ }^{127}$ (npr. osnivanje obrta, trgovačkog društva) i slobodu pružanja usluga $^{128}$ (privremeno pružanje usluga u drugoj državi članici bez osnivanja poslovnog nastana). Slično kao i kod slobode kretanja radnika, navedene odredbe ne primjenjuju se u djelatnostima povezanima s izvršavanjem javnih ovlasti, te

121 Više vidi u čl. 29. Direktive 2004/38.

122 Npr.C-325/08 od 16. ožujka 2010., Olympique Lyonnais/Bernard, ECLI:EU:C:2010:143.

123 Npr. C-632/13, Hirvonen, od 19. studenoga 2015., ECLI:EU:C:2015:765.

124 Npr. C-515/14 od 21. siječnja 2016., Komisija/Cipar, 21. siječnja 2016., ECLI:EU:C:2016:30, t. 53 i 54.

125 Sud EU-a, C-341/05 od 18. prosinca 2007., Laval, ECLI:EU:C:2007:809, t. 103.

126 Više vidi npr. u: Barnard, op. cit. u bilj. 85, str. 164 - 166.

127 Čl. 49. - 55. UFEU-a.

128 Čl. 56. - 62. UFEU-a. 
su pod uvjetom načela razmjernosti ograničenja moguća u svrhu zaštite javnog poretka, javne sigurnosti ili javnog zdravlja te eventualno drugih opravdanih interesa. ${ }^{129}$

Upućeni radnik (prije su se koristili još i pojmovi "izaslani radnik" i "detaširani radnik" te jedno vrijeme potpuno neprimjeren pojam "raspoređeni radnik"; ${ }^{130}$ engl. posted worker, njem. entsandter Arbeitnehmer, franc. travailleur détaché) ${ }^{131}$ osoba je koja privremeno pruža uslugu u ime i za račun svojeg poslodavca u drugoj državi članici od one u kojoj uobičajeno radi. Produžena je ruka poslodavca u ostvarivanju njegova prava kao poduzetnika na slobodu pružanja usluga u EUu. ${ }^{132}$ Upravo ga ta privremenost rada razlikuje od ostalih radnika migranata koji se žele integrirati u tržište rada druge države članice. Međutim, zbog razlika u plaćama između država članica upućeni radnici mogu postati poluga tzv. socijalnog dampinga domaćih radnika. ${ }^{133}$ Stoga se već godinama nastoji urediti rad upućenih radnika i ograničiti zlouporabu tog pravnog instituta. ${ }^{134} \mathrm{Za}$ sada to područje uređuju tri direktive EU-a.

Direktiva 96/71/EZ o upućivanju radnika u okviru pružanja usluga uređuje tri skupine upućenih radnika: 1) radnike upućene drugom poduzetniku da u ime i za račun poduzetnika/poslodavca pruže neku uslugu ili obave posao, 2) radnike upućene drugom povezanom poduzetniku, 3) radnike koje agencija za privremeno zapošljavanje ustupa korisniku (tzv. ustupljeni radnik, engl. hired-out worker). ${ }^{135}$ Direktiva 96/71/EZ promiče transnacionalno pružanje usluga uz primjenu načela tržišnog natjecanja. Međutim, radi djelomičnog sprečavanja

129 Više vidi u: Craig et al., op. cit. u bilj. 107, str. 764 - 818. O utjecaju propisa unutarnjeg tržišta EU-a na radno pravo vidi Barnard, op. cit. u bilj. 85, str. 189 - 250.

130 Pojam pogrešno uveden u hrvatski pravni sustav 2011., što je ispravljeno 2017. (Zakon o strancima, Narodne novine, br. 130/2011, 74/2013, 69/2017).

131 O pojmovnim dvojbama vidi i Baloković, S., Jesu li izaslani, upućeni, raspoređeni $i$ ustupljeni radnik istoznačnice prema hrvatskom zakonodavstvu, Radno pravo, br. 3, 2015. str. 3 - 16.

132 Čl. 2. Direktive 96/71/EZ definira “upućenog radnika" kao "radnika koji u ograničenom vremenskom razdoblju obavlja svoj posao na državnom području države članice koja nije država u kojoj uobičajeno radi".

133 To je zbog toga što sloboda pružanja usluga i poslovnog nastana u pravilu nije podložna prijelaznim ograničenjima za državljane iz novih država članica (osim u Austriji i Njemačkoj).

134 Više o upućivanju radnika u pravu EU-a vidi u: Grgić, A., Upućivanje radnika u okviru pružanja usluga u pravu EU, doktorski rad, Pravni fakultet Sveučilišta u Zagrebu, Zagreb, 2016.

135 Više vidi u čl. 1. Direktive 96/71/EZ. 
tzv. socijalnog dampinga, predmetna direktiva osigurava minimalnu zaštitu, propisujući primjenu prava države domaćina u pogledu minimalne plaće, radnog vremena, trajanja godišnjih odmora, jednakog postupanja, zaštite na radu itd. Također su propisane i iznimke, npr. u slučaju upućivanja radnika kraćeg od mjesec dana, ili u slučaju specijaliziranog početnog sastavljanja ili ugradnje isporučene robe $u$ trajanju kraćem od osam dana. ${ }^{136}$ Važno je još spomenuti da upućeni radnici u pravilu ostaju osigurani u sustavu socijalnog osiguranja u državi uobičajenog rada pod uvjetom da predviđeno trajanje posla u drugoj državi članici nije duže od 24 mjeseca i da nisu poslani kao zamjena za drugog upućenog radnika. ${ }^{137} \mathrm{U}$ tu im svrhu nadležna institucija države osiguranja izdaje tzv. Al potvrdu (nekoć E 101). Premda u pravilu takva potvrda ima dokaznu snagu u drugoj državi članici ${ }^{138}$, u slučaju sumnje u prijevaru nacionalni sudovi druge države članice mogu odbiti uporabu te potvrde kada se institucija izdavatelja ne očituje u razumnom roku, odnosno ponovno ne ispita osnovanost izdavanja potvrde. ${ }^{139}$

Tijekom 2014. godine donesene su dvije direktive. Direktiva 2014/67/EU provedbena je direktiva za Direktivu 96/71/EZ. Ima nekoliko ciljeva: 1) utvrđivanje istinskog upućivanja i sprečavanje zlouporabe i zaobilaženja propisa (uz primjerično navođenje kriterija provjere), 2) olakšani pristup informacijama o uvjetima zaposlenja i nacionalnom pravu i praksi (posebno u pogledu minimalne plaće), 3) administrativnu suradnju i uzajamnu pomoć između država članica. ${ }^{140}$ Direktiva 2014/66/EU propisuje uvjete za ulazak i boravak državljana iz trećih zemalja, i to za rukovoditelje, stručnjake i pripravnike, koji se premještaju iz poduzeća s poslovnim nastanom izvan EU-a u povezana društva (poduzeća ili skupine poduzeća) osnovana u državama članicama EU-a. Te se osobe nazivaju "ICT" zaposlenicima. ${ }^{141}$

136 Vidi čl. 3 Direktive 96/71/EZ.

137 Čl. 12. Uredbe 883/2004. Vidi i Crnjac Pauković, V., Izaslanja prema uredbama EU (potvrda Al), Računovodstvo, revizija i financije, br. 8, 2013., str. 78 - 86; Crnjac Pauković, V., Mogućnost rada u zemljama Europske unije - izaslanje i sloboda kretanja radnika, Radno pravo, br. 7-8, 2013., str. 3 - 14.

138 C-620/15 od 27. travnja 2017., A-Rosa Flussschiff, ECLI:EU:C:2017:309.

139 C-359/16 od 6. veljače 2018., Altun i dr., ECLI:EU:C:2018:63.

140 Također vidi Kasunić Peris, M., Novine u normativnom uređenju upućivanja radnika na rad u inozemstvo u kontekstu prekograničnog pružanja usluga prema Direktivi 2014/67/EU, Radno pravo, br. 4, 2016., str. 37 - 44.

141 ICT je kratica koja dolazi od engleskog pojma intra-corporate transferee (hrv. 'osoba premještena unutar društva') te se službeno koristi kao kratica u hrvatskom prijevodu direktive za posebne dozvole za takve zaposlenike. 


\subsection{Prijelazni režim za državljane iz novih država članica}

Zbog straha od jeftine i brojne radne snage stare države članice izborile su se u proširenjima na siromašnije i nezaposlenošću suočene nove države članice za kontrolu priljeva radne snage za vrijeme prijelaznog razdoblja. Prijelazne mjere, koje se od 1. srpnja 2013. primjenjuju i na Hrvatsku, zamišljene su kao postupno smanjujuće te se uobičajeno na njih poziva kao na "2+3+2-godišnje razdoblje". ${ }^{142}$ Ukupno smiju trajati najduže sedam godina, dakle najduže do 1. srpnja 2020.

Tijekom prvog prijelaznog razdoblja, koje obuhvaća prve dvije godine nakon pristupanja, stare države članice imaju pravo u primjeni derogirati odredbe o slobodnom kretanju radnika. Stoga pristup tržištima rada tih zemalja ovisi o nacionalnom pravu i mjerama kao i eventualnim bilateralnim sporazumima koje neke od njih imaju s ponekom novom državom članicom. Dodatno, Austrija i Njemačka smiju uvesti dopunska ograničenja za upućene radnike u svrhu pružanja usluga u određenim sektorima. ${ }^{143}$ Međutim, sukladno sudskoj praksi Suda EU-a u predmetu Vicoplus i dr., odredbe o slobodi pružanja usluga ne sprečavaju ni druge države članice da za vrijeme prijelaznog razdoblja ustupljene radnike (radnike koje agencija za privremeno zapošljavanje ustupa korisnicima) podvrgnu nacionalnom režimu, pa čak i radnim dozvolama. ${ }^{144}$ Smatramo da je ova presuda donesena pod snažnim utjecajem gospodarske krize i socijalnog dampinga kao posljedice pravila o slobodi pružanja usluga, pa je Sud takvom presudom tome doskočio. Za vrijeme druge faze, koja može trajati najduže tri godine, stare države članice smiju nastaviti s primjenom svojih mjera, o čemu trebaju obavijestiti Europsku komisiju. U pravilu bi primjena prijelaznih mjera trebala prestati u roku od pet godina. Međutim, u slučaju ozbiljnih poremećaja na tržištu rada ili takve ozbiljne prijetnje, država članica smije iznimno, nakon što obavijesti Europsku komisiju, nastaviti s daljnjom primjenom nacionalnih mjera za razdoblje od najduže dvije godine (treće prijelazno razdoblje). Dodatno, ako tijekom prijelaznog razdoblja neka stara država članica prestane primjenjivati svoje nacionalne mjere te započne s primjenom pravila o slobodi kretanja radnika, ta država može iznimno tražiti odobrenje za ponovno uvo-

142 Vidi dodatak 5. Ugovora o pristupanju Republike Hrvatske Europskoj uniji (SL L 112, 24. travnja 2012.). Napominjemo da se pravila EU-a o koordinaciji sustava socijalne sigurnosti primjenjuju bez ikakve iznimke na sve od trenutka pristupanja.

${ }_{143}$ Npr. Njemačka u području građevinarstva, industrijskog čišćenja i unutarnjeg uređenja, a Austrija u području hortikulture, rezanja i obrade kamena, proizvodnji metalnih konstrukcija i njihovih dijelova, građevinarstvu, zaštitarskoj djelatnosti, industrijskom čišćenju, njezi u kući i socijalnom radu.

${ }_{144}$ C-307/09, C-308/09iC-309/09 od 10. veljače2011., Vicoplusidr., ECLI:EU:C:2011:64. 
đenje nacionalnih mjera (tzv. sigurnosna klauzula; engl. safeguard clause). U takvoj situaciji Europska komisija ima ovlast odlučivati o vrsti mjera i njihovu trajanju. ${ }^{145}$ Ukupno trajanje prijelaznih mjera ne može ni u kojem slučaju biti protegnuto na razdoblje duže od sedam godina.

Opisani prijelazni režim ne odnosi se na osobe iz nove države članice koje zakonito rade u nekoj od starih država članica na dan pristupanja ili dan nakon pristupanja i koje imaju pristup tržištu rada te države članice za neprekinuto razdoblje od 12 mjeseci ili duže. Međutim, takvi radnici, premda imaju slobodan pristup tržištu dotične države članice, nemaju automatski osiguran slobodan pristup tržištima rada drugih starih država članica. ${ }^{146}$ Status člana obitelji takvog radnika (radnika iz nove države članice koji je zakonito zaposlen u staroj državi članici na razdoblje od 12 mjeseci ili duže) prijeporan je. U slučaju kada član obitelji ima zakonito boravište zajedno s radnikom na teritoriju neke stare države članice na dan pristupanja, takav će član obitelji također imati slobodan pristup tržištu rada te stare države članice. Međutim, ako se članovi obitelji pridruže radnicima nakon dana pristupanja, oni će imati pristup tržištu rada dotične stare države članice tek nakon što su boravili na njezinu teritoriju 18 mjeseci ili nakon proteka tri godine od pristupa, što god nastupi prije. Napominjemo da je njihov položaj nepovoljniji od položaja članova obitelji koji proizlazi iz odredbe čl. 45 st. l. al. 2. Sporazuma o stabilizaciji i pridruživanju (SSP). ${ }^{147}$ Stoga smatramo da SSP treba tumačiti kao propis na snazi u trenutku potpisivanja Ugovora o pristupanju, pa je, dakle, putem primjene klauzule o mirovanju moguće da se član obitelji poziva na pravo na pristup tržištu rada i za vrijeme koje nije pokriveno odredbama Ugovora o pristupanju.

Potrebno je istaknuti da je diskrecijska ovlast stare države članice tijekom prijelaznog razdoblja podvrgnuta dvama ograničenjima. Jedno je "klauzula o mirovanju" (engl. standstill clause), koja zabranjuje starim državama članicama da na državljane novih država članica primjenjuju teže uvjete pristupu tržištu rada od onih koji su bili na snazi na dan potpisivanja Ugovora o pristupanju. ${ }^{148}$

145 Do sada je to pravo jedino iskoristila Španjolska u slučaju državljana Rumunjske (uvedeno 22. lipnja 2011.).

146 Priklanjamo se mišljenju Adinolfi prema kojem bi puno razumnije rješenje bilo dopustiti takvim posebnim kategorijama državljana novih država članica potpunu slobodu zapošljavanja u svim drugim starim državama članicama, a ne samo u toj u kojoj već zakonito rade (vidi Adinolfi, A., Free movement and access to work of citizens of the new Member States: The transitional measures, Common Market Law Review, vol. 42, br. 2, 2005., str. 493).

147 Narodne novine, Međunarodni ugovori, br. 14/2001.

148 Ugovor o pristupanju Republike Hrvatske Europskoj uniji, SL L 112, 24. travnja 2012., prilog V., članak 2., točka 13, prvi podstavak. 
Drugo ograničenje se očituje u načelu prvenstva radnika iz EU-a, što znači da stara država članica koja pribjegne nacionalnim mjerama tijekom prijelaznog razdoblja mora dati prednost radnicima odnosno tražiteljima zaposlenja iz nove države članice u odnosu na ostale iz trećih država. ${ }^{149}$

U zamjenu za dugo i restriktivno prijelazno razdoblje nove države članice imaju pravo uvesti recipročne mjere za radnike onih starih država članica koje na njihove radnike primjenjuju prijelazne mjere. To pravo iskoristile su Mađarska, Poljska, Slovenija te Hrvatska. ${ }^{150}$ Mogućnost uvođenja recipročnih mjera dopuštena je samo u odnosu na onu državu članicu koja primjenjuje prijelazne mjere. Nije riječ o identičnim mjerama, s obzirom na to da je i nova država članica vezana također klauzulom o mirovanju.

Mogućnosti zadržavanja nacionalnih mjera tijekom prijelaznog razdoblja rezultirale su različitim imigracijskim rješenjima, koja su s protekom vremena podložna promjenama. Tako je npr. u odnosu na Hrvatsku u prvoj fazi (1. srpnja 2013. - 1. srpnja 2015.) čak 13 starih država članica ograničilo pristup svojem tržištu ${ }^{151}$, dok je tijekom druge faze prijelaznog razdoblja (od 1. srpnja 2015. do 30. srpnja 2018.) samo pet država nastavilo s kontrolnim i restriktivnim režimom. ${ }^{152}$ Ostale države primjenjuju režim slobode kretanja radnika i slobode pružanja usluga.

\section{ZAKLJUČAK}

Mobilnost radne snage $\mathrm{u}$ EU-u jedan je od načina da se radnicima zajamči mogućnost poboljšanja uvjeta života i rada te da se potakne njihov socijalni boljitak, a da se istodobno omogući udovoljavanje zahtjevima gospodarstava država članica. Vidjeli smo da znatan doprinos u razvoju pravnih aspekata slobode kretanja ima i Sud EU-a. Iz analize sudske prakse očito je da se područje primjene temeljnih sloboda kretanja često tumači ekstenzivno, a iznimke i ograničenja vrlo restriktivno.

Međutim, iz opisanog pravnog okvira možemo uočiti suprotstavljena nastojanja na razini EU-a u odnosu na nacionalnu razinu država članica. Naime, EU je suočen s kvalifikacijskim i demografskim problemima, pa te srednjoročne i

149 Ibid., drugi i treći podstavak.

150 Za Hrvatsku vidi Uredbu o privremenoj primjeni pravila o radu državljana država članica Europske unije i članova njihovih obitelji (Narodne novine, br. 79/2013).

151 Austrija, Belgija, Cipar, Francuska, Njemačka, Grčka, Italija, Luksemburg, Malta, Nizozemska, Španjolska, Slovenija i UK.

152 Austrija, Malta, Nizozemska, Slovenija i UK. 
dugoročne probleme nastoji riješiti migracijskom politikom i stvaranjem privlačne klime za rad stranaca, posebno mlađih osoba i visokokvalificiranog kadra čije je školovanje skupo. Nasuprot tome, migranti koliko god potrebni bili, u državama člancima percipirani su kao izvor socijalnih i kulturoloških problema $s$ kratkoročnim i dugoročnim posljedicama, posebno ako je riječ o ekonomski neaktivnim osobama. Nezadovoljstvo domaćeg stanovništva imigrantima postaje problem održivosti političke elite, pa su stoga države članice sklone iskoristiti sve dopuštene mjere. Tako je i u slučaju proširenja EU-a na Hrvatsku velik broj država u uvjetima gospodarske krize aktivirao prijelazna razdoblja. Nažalost, unatoč tim ograničavajućim mjerama, primjetan je velik broj odlazaka mladih i obrazovanih iz Hrvatske.

Trebamo biti svjesni da opasnost od odljeva najbolje radne snage uvijek postoji, osobito ako je situacija u domovini loša, a potražnja za kvalitetnim kadrovima u drugim državama velika. To sve može imati dalekosežne i višestruke nepovoljne demografske, strukturne i razvojne ishode. Kod toga se treba ponovno podsjetiti da veće gubitke po osnovi odljeva visokoobrazovane snage trpe male zemlje, poput Hrvatske, jer je takav odljev proporcionalno veći u odnosu na njihovu ukupnu populaciju. Nadalje, gospodarski rast ovisi i o rastu stanovništva i o tehnološkom napretku. Stoga bi vladama, posebice u Hrvatskoj, trebale biti važne mjere usmjerene na smanjenje želje za emigriranjem domicilnog stanovništva, dakle mjere usmjerene na gospodarski razvoj i zapošljavanje, ublažavanje siromaštva i političku stabilnost i pravnu sigurnost.

\section{LITERATURA}

\section{Knjige, članci i dokumenti}

Adinolfi, A., Free movement and access to work of citizens of the new Member States: The transitional measures, Common Market Law Review, vol. 42, br. 2, 2005. str. $469-498$.

Akrap, A., Promjene broja i prostornog razmještaja stanovništva Hrvatske i županija, u: Puljiz, V. et al. (ur.), Migracije i razvoj Hrvatske: podloga za hrvatsku migracijsku strategiju, Hrvatska gospodarska komora, Zagreb, 2014., str. 25 - 71.

Arslan, C.; Dumont, J.; Kone, Z.; Moullan, Y.; Ozden, C; Parsons, C; Xenogiani; T., A New Profile of Migrants in the Aftermath of the Recent Economic Crisis, OECD Social, Employment and Migration Working Papers, br. 160, 2014., OECD Publishing, http://dx.doi.org/10.1787/5jxt2t3nnjr5-en (15. svibnja 2016.).

Baloković, S., Jesu li izaslani, upućeni, raspoređeni i ustupljeni radnik istoznačnice prema hrvatskom zakonodavstvu, Radno pravo, br. 3, 2015., str. 3 - 16. 
Barnard, C., EU Employment Law. Oxford University Press, Oxford, 2012.

Barslund, M.; Busse, M.; Schwarzwälder, J., Labour Mobility in Europe: An untapped resource?, Centre for European Policy Studies, Policy Brief, br. 327, 2015. https://www.ceps.eu/system/files/Labour\%20Mobility\%20PB\%20joint\%20 Bertelsmann\%20FINAL\%20mb.pdf (15. svibnja 2016.).

Bejaković, P., Obrazovanje, Tržište rada i mobilnost radne snage u Hrvatskoj - stanje i problemi, u: Puljiz, V. et al. (ur.), Migracije i razvoj Hrvatske: podloga za hrvatsku migracijsku strategiju, Hrvatska gospodarska komora, Zagreb, 2014., str. 93 - 118.

Canetta, E.; Fries-Tersch, E.; Mabilia, V., 2014 Annual report on statistics on intra-EU movers, European Commission, September 2014., http://ec.europa.eu/social/ contentAdmin/BlobServlet?docId=13484\&langId=en (10. siječnja 2016.).

Craig P.; De Burca G., EU Law - Texts, cases and materials, 5. izdanje, Oxford University Press, New York, 2011.

Crnjac Pauković, V., Izaslanja prema uredbama EU (potvrda Al), Računovodstvo, revizija i financije, br. 8, 2013., str. $78-86$.

Crnjac Pauković, V., Mogućnost rada u zemljama Europske unije - izaslanje i sloboda kretanja radnika, Radno pravo, br. 7-8, 2013., str. 3 - 14.

Čačić-Kumpes, J.; Gregurović, S.; Kumpes, J., Migracija, integracija i stavovi prema imigrantima u Hrvatskoj, Revija za sociologiju, vol. 42, br. 3, 2012., str. 305 - 336.

Čavrak, V., Utjecaj migracija visokoobrazovanih stručnjaka na razvoj Hrvatske, u: Puljiz, V. et al. (ur.), Migracije i razvoj Hrvatske: podloga za hrvatsku migracijsku strategiju, Hrvatska gospodarska komora, Zagreb, 2014., str. 117 - 130.

Davies, A., EU Labour Law, Edward Elgar, Cheltenham, 2012.

European Commission, Enlargement - Transitional periods, http://ec.europa.eu/ employment_social/free_movement/enlargement_en.htm (17. siječnja 2007.)

European Commission, Commission Staff Working Document Accompanying Report on the Functioning of the Transitional Arrangements on Free Movement of Workers from Croatia (First phase: 1 July 2013 - 30 June 2015), SWD (2015) 107 final, 29. svibnja 2015.

European Commission, Communication From the Commission to the European Parliament, the Council, the European Economic and Social Committee and the Committee of the Regions: Free Movement of EU Citizens and their Families: Five Actions to make a difference, COM (2013) 837 final, 25. studenoga 2013.

European Commission, Report on the Functioning of the Transitional Arrangements set out in the 2003 Accession Treaty (period I May 2004 - 30 April 2006). COM (2006) 48 final, 8. veljače 2006. 
European Commission, Report on the Functioning of the Transitional Arrangements on Free Movement of Workers from Croatia (First phase: 1 July 2013 - 30 June 2015), COM (2015) 233 final, 29. svibnja 2015.

Fries-Tersch, E.; Tugran, T.; Bradley, H., 2016 Annual Report on intra- EU Labour Mobility, European Commission, 2. izdanje, svibanj 2017., http://ec.europa. $\mathrm{eu} /$ social/BlobServlet?docId=17165\&langId=en (10. veljače 2018.).

Giulietti, C., Is The Minimum Wage A Pull Factor For Immigrants?, Industrial and Labor Relations Review, vol. 67, br. 3, 2014., str. $649-674$.

Gregurović, S., Utjecaj eurointegracijskih procesa na migracije - lekcije za Hrvatsku, u: Puljiz, V. et al. (ur.), Migracije i razvoj Hrvatske: podloga za hrvatsku migracijsku strategiju, Hrvatska gospodarska komora, Zagreb, 2014., str. 271 - 284.

Kasunić Peris, M., Novine u normativnom uređenju upućivanja radnika na rad u inozemstvo u kontekstu prekograničnog pružanja usluga prema Direktivi 2014/67/EU, Radno pravo, br. 4, 2016., str. 37 - 44.

Mesić, M., Međunarodne migracije, u: Puljiz, V. et al., Migracije i razvoj Hrvatske: podloga za hrvatsku migracijsku strategiju, Hrvatska gospodarska komora, Zagreb, 2014., str. 157 - 174.

O'Leary, S. The Free Movement of Persons and Services, u: Craig, P.; de Búrca, G. (ur.), The Evolution of EU Law, Oxford University Press, New York, 1999., str. 377 - 416.

O’Brien, C.; Spaventa, E.; De Coninck, J., Comparative Report 2015: The concept of worker under Article 45 TFEU and certain non-standard forms of employment, European Commission, Brussels, 2016., http://ec.europa.eu/social/BlobServlet?docId $=15476 \&$ langId=en (5. lipnja 2016.).

Obadić, A., Posljedice ekonomske krize na tržište rada i mobilnost radne snage u EU i RH, u: Puljiz, V. et al. (ur.), Migracije i razvoj Hrvatske: podloga za hrvatsku migracijsku strategiju. Hrvatska gospodarska komora, Zagreb, 2014., str. 131 - 156.

OECD (2013.), International Migration Outlook 2013, OECD Publishing, Pariz, http://dx.doi.org/10.1787/migr_outlook-2013-en (15. prosinca 2015.).

OECD (2015.), International Migration Outlook 2015, OECD Publishing, Pariz, http://dx.doi.org/10.1787/migr_outlook-2015-en (15. prosinca 2015.).

Puljiz, V., Migracije i imigracijske politike u Europi, u: Puljiz, V. et al. (ur.), Migracije i razvoj Hrvatske: podloga za hrvatsku migracijsku strategiju, Hrvatska gospodarska komora, Zagreb, 2014., str. 251 - 270.

Ravnić, A.; Potočnjak, Ž., Pravni aspekti odlaska stručnjaka u inozemstvo, Institut za društvena istraživanja Sveučilišta u Zagrebu, Zagreb, 1986.

Skupnjak Kapić, S., Migracije radne snage - globalni i europski trendovi s osvrtom na Hrvatsku, u: Puljiz, V. et al. (ur.), Migracije i razvoj Hrvatske: podloga za hrvatsku migracijsku strategiju, Hrvatska gospodarska komora, Zagreb, 2014., str. 217 - 250. 
Tintić, N., Radno i socijalno pravo, Knjiga prva: Radni odnosi (II), Narodne novine, Zagreb, 1972.

Urso, G.; Schuster A., Migration, Employment and Labour Market Integration Policies in the EU (2011), International Organisation for Migration, Brussels, 2013.

Van Overmeiren, F.; O’Brien, C.; Spaventa, E.; Jorens, Y.; Schulte, B., Analytical Report 2014. The notion of obstacle and discrimination under EU law on free movement of workers, FreSsco, European Commission, December 2014, http://ec.europa. $\mathrm{eu} /$ social/BlobServlet?docId=13535\&langId=en (20. rujna 2015.).

Vonk, G.; van Walsum, S., Towards a new approach to social protection for formally excluded migrants, u: Vonk, G. (ur.), Cross Border Welfare State: Immigration, Social Security and Integration, Intersentia, Cambridge, 2012., str. 3 - 60.

Vukorepa, I., Sloboda kretanja osoba, u: Mintas-Hodak, Lj., Uvod u Europsku uniju, Mate d.o.o., Zagreb, str. 127 - 141.

Vukorepa, I., Sloboda kretanja radnika u Europskoj uniji, Godišnjak Tribine Pravnog fakulteta Sveučilišta u Zagrebu i Kluba pravnika Grada Zagreba, Pravni fakultet Sveučilišta u Zagrebu, Zagreb, 2013., str. 21 - 43.

Vukorepa, I., Sloboda kretanja radnika: izazovi i zamke za Hrvatsku, Radno pravo, br. 2, 2006., str. 5 - 14 .

WEF (2016.), The Future of Jobs: Employment, Skills and Workforce Strategy for the Fourth Industrial Revolution, World Economic Forum, 2016., http://www3. weforum.org/docs/WEF_Future_of_Jobs.pdf (8. ožujka 2016.).

World Bank, Migration and Remittances Factbook, 3. izdanje, The World Bank, Washington, 2016.

Ziller, J., Free Movement of European Union Citizens and Employment in the Public Sector, European Commission, 2010., Part I-General Report: http://ec.europa. $\mathrm{eu} /$ social/BlobServlet?docId=6401\&langId=en (25. rujna 2015.).

Župarić-Iljić, D.; Bara, M., Unutrašnje i vanjske migracije u Hrvatskoj: povijesni i suvremeni kontekst. u: Puljiz, V. et al. (ur.), Migracije i razvoj Hrvatske: podloga za hrvatsku migracijsku strategiju, Hrvatska gospodarska komora, Zagreb, 2014., str. $197-216$.

\section{Pravni izvori}

Direktiva 1977/486/EEZ od 25. srpnja 1977. o obrazovanju djece radnika migranata (SL L 199, 6. kolovoza 1977., str. 32 - 33, SL, posebno izdanje na hrvatskom jeziku, poglavlje 05, svezak 001, str. 7 - 8).

Direktiva 2004/114/EZ od 13. prosinca 2004. o uvjetima prihvata državljana trećih zemalja u svrhu studija, razmjene učenika, osposobljavanja bez nakna- 
de ili volonterstva (SL L 153M , 7. lipnja 2006., str. 330 - 336; SL, posebno izdanje na hrvatskom jeziku, poglavlje 19, svezak 012, str. 78 - 84).

Direktiva 2004/38/EZ Europskog parlamenta i Vijeća od 29. travnja 2004. o pravu građana Unije i članova njihovih obitelji na slobodno kretanje i boravište na području države članice (...), Tekst značajan za EGP (SL L 158, 30. travnja 2004., str. 77 - 123; SL, posebno izdanje na hrvatskom jeziku, poglavlje 05, svezak 002, str. $42-55)$.

Direktiva 2005/36/EZ Europskog parlamenta i Vijeća od 7. rujna 2005. o priznavanju stručnih kvalifikacija, Tekst značajan za EGP, (SL L 255, 30. rujna 2005., str. 22 - 142; SL, posebno izdanje na hrvatskom jeziku, poglavlje 05, svezak 001, str. $125-245)$.

Direktiva 2005/71/EZ od 12. listopada 2005. o posebnom postupku za ulazak državljana trećih zemalja u svrhu znanstvenog istraživanja (SL L 289, 3. studenoga 2005., str. 15 - 22; SL, posebno izdanje na hrvatskom jeziku, poglavlje 19, svezak 003, str. 216 - 223).

Direktiva 2009/50/EZ od 25. svibnja 2009. o uvjetima za ulazak i boravak državljana trećih zemalja radi visokokvalificiranog zapošljavanja (SL L 155, 18. lipnja 2009., str. 17 - 29; SL, posebno izdanje na hrvatskom jeziku, poglavlje 19, svezak 011, str. 135 - 147).

Direktiva 2009/52/EZ od 18. lipnja 2009. o minimalnim standardima za sankcije i mjere za poslodavce državljana trećih zemalja s nezakonitim boravkom (SL L 168, 30. lipnja 2009., str. 24 - 32; SL, posebno izdanje na hrvatskom jeziku, poglavlje 19, svezak 013, str. 133 - 141).

Direktiva 2011/98/EU od 13. prosinca 2011. o jedinstvenom postupku obrade zahtjeva za izdavanje jedinstvene dozvole za boravak i rad državljanima trećih zemalja na državnom području države članice te o zajedničkom skupu prava za radnike iz trećih zemalja koji zakonito borave u državi članici (SL L 343, 23. prosinca 2011., str. 1 - 9; SL, posebno izdanje na hrvatskom jeziku, poglavlje 05, svezak 006, str. $303-311$ ).

Direktiva 2014/36/EU od 26. veljače 2014. o uvjetima za ulazak i boravak državljana trećih zemalja u svrhu zapošljavanja u statusu sezonskih radnika (SL L 94, 28. ožujka 2014., str. 375 - 390).

Direktiva 2014/50/EU Europskog parlamenta i Vijeća od 16. travnja 2014. o minimalnim zahtjevima za poboljšanje mobilnosti radnika među državama članicama unaprjeđivanjem stjecanja i očuvanja prava na dopunsku mirovinu, Tekst značajan za EGP (SL L 128, 30. travnja 2014., str. 1 - 7).

Direktiva 2014/54/EU Europskog parlamenta i Vijeća od 16. travnja 2014. o mjerama za lakše ostvarivanje prava zajamčenih radnicima $u$ kontekstu 
slobode kretanja radnika, Tekst značajan za EGP (SL L 128, 30. travnja 2014., str. 8 - 14).

Direktiva 2014/66/EU od 15. svibnja 2014. o uvjetima za ulazak i boravak državljana trećih zemalja u okviru premještaja unutar društva (SL L 157, 27. svibnja 2014., str. I - 22).

Direktiva 2014/66/EU od 15. svibnja 2014. o uvjetima za ulazak i boravak državljana trećih zemalja u okviru premještaja unutar društva (SL L 157, 27. svibnja 2014., str. 1 - 22).

Direktiva 2014/67/EU o provedbi Direktive 96/71/EZ i izmjeni Uredbe (EU) br. 1024/2012 o administrativnoj suradnji putem Informacijskog sustava unutarnjeg tržišta (SL L 159, 28. svibnja 2014., str. 11 - 31).

Direktiva Vijeća 98/49/EZ od 29. lipnja 1998. o zaštiti prava na dopunsku mirovinu zaposlenih i samozaposlenih osoba koje se kreću unutar Zajednice (SL L 209, 25. srpnja 1998., str. 46-49; SL, posebno izdanje na hrvatskom jeziku, poglavlje 05, svezak 003, str. 138 - 141);

Direktive 96/71/EZ Europskog parlamenta i Vijeća od 16. prosinca 1996. o upućivanju radnika u okviru pružanja usluga (SL 18, 21. siječnja 1997., str. I -6).

Europska konvencija za zaštitu ljudskih prava i temeljnih sloboda, Narodne novine, Međunarodni ugovori, br. 18/1997, 6/1999, 14/2002, 13/2003, 9/2005, 1/2006, 2/2010.

Sporazum o stabilizaciji i pridruživanju između Republike Hrvatske, s jedne strane, i Europskih zajednica i njihovih država članica, s druge strane, Narodne novine, Međunarodni ugovori, br. 14/0.

Ugovor o funkcioniranju Europske unije (pročišćena inačica iz 2016.), SL, C 202, 7. lipnja 2016.

Uredba (EU) 2016/1191 Europskog parlamenta i Vijeća od 6. srpnja 2016. o promicanju slobodnog kretanja građana pojednostavnjenjem zahtjeva za predočavanje određenih javnih isprava u Europskoj uniji i o izmjeni Uredbe (EU) br. 1024/2012, SL L 200, 26. srpnja 2016., str. 1 - 136.

Uredba (EU) 2016/589 Europskog parlamenta i Vijeća od 13. travnja 2016. o Europskoj mreži službi za zapošljavanje (EURES), pristupu radnika uslugama mobilnosti i daljnjoj integraciji tržišta rada i izmjeni uredaba (EU) br. 492/2011 i (EU) br. 1296/2013 (Tekst značajan za EGP), SL L 107, 22. travnja 2016., str. $1-28$.

Uredba (EU) br. 492/2011 Europskog parlamenta i Vijeća od 5. travnja 2011. o slobodi kretanja radnika u Uniji (kodifikacija), Tekst značajan za EGP, (SL L 141, 27. svibnja 2011., str. I - 12; SL, posebno izdanje na hrvatskom jeziku, poglavlje 05, svezak 002, str. $264-275$ ). 
Uredba (EZ) br. 883/2004 Europskog parlamenta i Vijeća od 29. travnja 2004. o koordinaciji sustava socijalne sigurnosti, sa zadnjim izmjenama iz 2013., (Tekst značajan za EGP i Švicarsku), SL L 166, 30. travnja 2004., str. 1 123; SL, posebno izdanje na hrvatskom jeziku, poglavlje 05, svezak 003, str. $160-204$.

Uredba (EZ) br. 987/2009 Europskog parlamenta i Vijeća od 16. rujna 2009. o utvrđivanju postupka provedbe Uredbe (EZ) br. 883/2004 o koordinaciji sustava socijalne sigurnosti, (Tekst značajan za EGP i Švicarsku), SL L 284, 30. listopada 2009., str. I - 42; SL, posebno izdanje na hrvatskom jeziku, poglavlje 05, svezak 002, str. 171 - 212 .

Uredba o privremenoj primjeni pravila o radu državljana država članica Europske unije i članova njihovih obitelji, Narodne novine, br. 79/2013.

Zakon o državnim službenicima, Narodne novine br. 92/2005, 140/2005, 142/2006, 77/2007, 107/2007, 27/2008, 34/2011, 49/2011, 150/2011, 34/2012, 38/2013, 37/2013, 1/2015, 138/2015, 61/2017.

Zakon o javnom bilježništvu, Narodne novine, br. 78/1993, 29/1994, 162/1998, 16/2007, 75/2009, 120/2016.

Zakon o potvrđivanju tzv. Ugovora o pristupanju Republike Hrvatske Europskoj uniji, Narodne novine, Međunarodni ugovori, br. 2/2012, 9/2013.

Zakon o strancima, Narodne novine, br. 130/2011, 74/2013, 69/2017.

Zakon o službenicima i namještenicima u lokalnoj i područnoj (regionalnoj) samoupravi, Narodne novine, br. 86/2008, 61/2011, 4/2018. 
Summary

Ivana Vukorepa *

\section{MIGRATIONS AND RIGHT TO WORK IN THE EUROPEAN UNION}

The purpose of this paper is to analyse and present the legal framework of the right to work in the European Union in the context of migration issues. Given that migrations in general, and in particular labour migrations, have various causes and important economic, social and demographic consequences, the first part of the paper presents the basic concepts, historical development and the features of migration. The most important socio-economic and legal aspects are also presented, as well as the labour market elements relevant to migration. The second part of the paper elaborates in detail the normative arrangement of labour migration in the EU. There is a clear distinction between the right to work of EU nationals and third country nationals. In the legal analysis, the author puts an emphasis on the areas of freedom of movement of workers, posting of workers, and the transitional regime for new Member States' nationals.

Key words: migration, freedom of movement for workers, EU, posting of workers

Ivana Vukorepa, Ph. D., Assistant Professor, Faculty of Law, University of Zagreb, Trg Republike Hrvatske 14, Zagreb; ivana.vukorepa@pravo.hr;

ORCID ID: orcid.org/0000-0001-6759-9992 